\title{
Liquefaction, landslide and slope stability analyses of soils: A case study of soils from part of Kwara, Kogi and Anambra states of Nigeria
}

\author{
Olusegun O. Ige ${ }^{1}$, Tolulope A. Oyeleke ${ }^{1}$, Christopher Baiyegunhi ${ }^{2}$, Temitope L. Oloniniyi ${ }^{2}$ \\ and Luzuko Sigabi ${ }^{2}$ \\ ${ }^{1}$ Department of Geology and Mineral Sciences, University of Ilorin, Private Mail Bag 1515, \\ Ilorin, Kwara State, Nigeria \\ ${ }^{2}$ Department of Geology, Faculty of Science and Agriculture, University of Fort Hare, Private \\ Bag X1314, Alice, 5700, Eastern Cape Province, South Africa \\ Corresponding Email Address: 201201530@ufh.ac.za
}

\begin{abstract}
Landslide is one of the most ravaging natural disaster in the world and recent occurrences in Nigeria require urgent need for landslide risk assessment. A total of nine samples representing three major landslide prone areas in Nigeria were studied, with a view of determining their liquefaction and sliding potential. Geotechnical analysis was used to investigate the liquefaction potential, while the slope conditions were deduced using SLOPE/W. The results of geotechnical analysis revealed that the soils contain 6-34 \% clay and 72-90\% sand. Based on the unified soil classification system, the soil samples were classified as well graded with group symbols of SW, SM and CL. The plot of plasticity index against liquid limit shows that the soil samples from Anambra and Kogi are potentially liquefiable. The liquefaction screening criteria also revealed that Anambra and Kogi are potentially susceptible to liquefaction, whereas samples from Kwara are not susceptible to liquefaction. Samples from Kogi and Anambra have lower values of MDD and OMC, ranging between 1.64-1.80 g/ $\mathrm{cm}^{3}$ and 8.0-12.3 $\%$ respectively. These values showed that the samples are granular material with soil having anticipated embankments performance, subgrade and base material as poor-fair, fair-good and good-poor, respectively. The direct shear strength test on the soil samples indicated that the cohesion and angle of internal friction varies between $40-80 \mathrm{kPa}$ and $24-35^{\circ}$. The Coefficient of permeability vary between $8.71 \times 10^{-5}$ and $1.18 \times 10^{-3}$. The factor of safety (FOS) values for soils from Anambra, Kogi and Kwara are 1.452, 1.946 and 2.488, respectively. These values indicate stability but care must be taken as the condition at the site shows that the slope is in its state of impending failure. The FOS for dry slope was higher when compared to the FOS values from wet slope. This was due to the effect of pore water pressure on the soil as it reduced the
\end{abstract}


shear strength of the soil. A reduced value of FOS was observed in the model under loading conditions, which indicate that loading is also a contributing factor to the slope failure. It is recommended that proper and efficient drainage system should be employed in these areas to reduce the influence of pore water pressure in the soil.

Keywords: Liquefaction, landslide, slope stability, geotechnical analyses, Nigeria

\section{INTRODUCTION}

40 The effect of natural disaster in the world cannot be over-emphasized, as a number of failures of embankments, natural slopes, earth structures and foundations have been attributed to the liquefaction of sands, landslides and slope instability. According to the report documented by National Research Council (1985), case studies of landslides or flow failures due to liquefaction are the 1937 Zeeland coast of Holland slides involving 7 million cubic meters of alluvial sands, and the 1944 Mississippi River slide near Baton Rouge containing about 4 million cubic meters of fine sands. Just to mention a few cases, failure of hydraulic fill dams such as the Calaveras Dam (California) in 1918, Fort Peck Dam (Montana) in 1938, and Lower San Fernando Dam (California) in 1971, were triggered by the liquefaction of sands. Landslides are a major hazard in Africa where resources worth several millions of dollars are lost annually during seasons of heavy and light rains. In West Africa, landslides are caused primarily by rainfall. Depending on meteorological and geomorphologic conditions, individual rainfall events can trigger small or large slope failures.

One of the most recent natural disasters threatening Nigeria is landslide. In Nigeria, landslide has done a serious destruction to physical structure and resulted in the loss of lives and properties. For instance, the December 2005 landslides in Umuchiani community of Anambra state has led to the inhabitation of about 250 families, while over 20 communities in Awgu and Oji-River Local Government Areas of Enugu State were thrown into serious difficulties by landslides cutting off a portion of the Awgu-Achi-Oji River Federal road in October 2011. According to the report documented by State Emergency Management Agency (SEMA), the landslide that occurred in Oko Community of Anambra State has rendered more than 150

61 people homeless. In addition, they reported that 15 buildings were destroyed, but no life was

62 lost. In 2013, no fewer than nine persons were buried alive, while many others sustained 63 injuries in the landslide that occurred at Edim Otop community of Calabar metropolis (Figure 

especially because they have generally been poorly defined in the past. The landslides have the potential to damage human settlements, industrial development, cattle ranch, forestry and agricultural activities. Landslide is mass movement on slope involving rock fall, debris flow, topples, and sliding (Varnes et al., 1984). Landslide occurs as result of the presence of saturated clay materials on the impermeable layer on steep slopes. Landslide that occurred on a slope is influenced by gravity. The internal and external causes of landslide is presented in Table 1 . The presence of soil moisture also increases the pore water pressure and lessens the material stability. A change in pore water pressure is regarded as the main triggering factor to land sliding (Ngecu and Mathu, 1999 and Knapen et al., 2006). If an external load is applied to a soil mass on a slope in the form of additional water or overburden, the pore water pressure will build up such that mass and water will be expelled at weak points (Alexander, 1993).

Slope instability is the condition which gives rise to slope movements (Alexander, 1993). In every slope, there are forces (stresses) that tend to instigate or cause movement (shear stress), and opposing forces which tend to resist movement (shear strength), (Bromhead, 1984; Alexander, 1993). Sliding occurs when shear stress is greater than shear strength. In normal circumstances, the shear stress is balanced by shear strength and a state of equilibrium is maintained (Alexander, 1993). However, this equilibrium can be disturbed by stress increments or weakening of frictional force. The failure of slope material depends partly on the strength of frictional force between the sliding mass and the bedrock (Crozier, 1984; Alexander, 1993; and Matsushi et al., 2006). Slope stability analysis can be performed using either total or effective stress. Total stress analysis is applicable to embankments and multistage loading problems where the short term condition is critical, while effective stress analysis should be used for excavation problems where the long-term condition is critical (Duncan, 1996). The search for the preparatory factors and cause(s) of an individual landslide or an attempt to designate the state of instability is prompted to find an efficient way of responding to the problem by legal necessity, or simply by a desire for knowledge (Crozier, 1984). The danger of slope instability can never be over emphasized in its destructive property. To understand and evaluate liquefaction potential of soils and degree of slope stability, as well as causes of landslide in the area, three localities (Anambra, Kogi and Kwara state, Figure 3) that differ in geology and land use were studied. While slope failure and landslides are common and frequent in the mountainous parts of Anambra and Kogi state because of their unique geology, long-time residents report that the recent landslides at Oko, in Anambra state (Figure 1) is the first major 

differences in scale and frequency were the major motivating factors for the research.

100

\section{GEOLOGICAL BACKGROUND}

Nigeria is a part of Africa that forms the continental crust and lies in the Pan-African mobile belt that has been affected by Pan- African events during the ages of orogenic, epeiorogenetic, tectonic and metamorphic cycles (Rahaman, 1976). The geology of Nigeria can be subdivided into the Precambrian Basement Complex and Cretaceous to Tertiary sedimentary basins. The Nigerian Basement Complex forms part of the Pan-African mobile belt and lies between the West African and Congo Cratons (Figure 3) and to the south of Tuareg Shield (Black, 1980). It consists of gneiss migmatite complex, schist belt and granitoids (older granites) of the Archean, Paleoproterozoic and Neoproterozoic (Annor, 1998). The Nigerian basement (Fig.2.1) was affected by the 600 Ma Pan-African orogeny and it occupies the reactivated region which resulted from plate collision between the passive continental margin of the West African craton and the active Pharusian continental margin (Burke and Dewey, 1972; Dada, 2006). About $50 \%$ of the total landmass of Nigeria is covered by sedimentary basins. These basins are Bida Basin, Benue Trough, Chad Basin, Anambra Basin, Dahomey Basin and Niger Delta Basin. The basins generally develop over the Precambrian basement and dominated by clastic deposit and in places, ironstone and organic coal-bearing sediments (NguimbousKouoh, 2012). The study area falls in both the Basement Complex and sedimentary areas. The areas under sedimentary part of Nigeria are Oko in Anambra State and Agbaja in Kogi State, while those in the Basement Complex are Eyenkorin and Asa Dam in Ilorin, Kwara State.

\subsection{Location of the study area}

\subsubsection{Oko, Anambra State}

Oko is situated in Orumba North Local Government Area (LGA) of Anambra state. It is geographically situated between $6^{\circ} 02^{\prime} 37.34^{\prime \prime} \mathrm{N}$ and $7^{\circ} 04^{\prime} 54.32^{\prime \prime} \mathrm{E}$ and has humid climatic condition. The average annual rainfall in Oko is about 2,000 mm. Most rainfall occurs in welldefined rainy seasons of six to seven months (April to October) and is typically concentrated in high intensity storms and often causes flooding and erosion leading to the formation of gullies. Oko is a rain forest area and is characterized by vast undulating landscape and of alluvial plain. Greater part of its vegetation is made up of forest (tropical vegetation). 
Nat. Hazards Earth Syst. Sci. Discuss., doi:10.5194/nhess-2016-297, 2016

\subsubsection{Agbaja, Kogi State}

Agbaja is the locality of a large iron ore deposit in Kogi State, central Nigeria. It is located on a plateau about $300 \mathrm{~km}$ south of the capital Abuja, and more importantly about $70 \mathrm{~km}$ from the heavy duty railway to the sea at Itakpe which is about $70 \mathrm{~km}$ to the south. It is geographically situated between $7^{\circ} 56^{\prime} 53.33^{\prime \prime} \mathrm{N}$ and 6 $6^{\circ} 9^{\prime} 38.40^{\prime \prime} \mathrm{E}$. The land rises from about $300 \mathrm{~m}$ along the Niger Benue confluence, to the heights of about $500 \mathrm{~m}$ above sea level in the uplands. Agbaja Plateau, which ranges from 335-366 m above sea level, is one of the predominant landforms in the state. The state is drained by the Niger and Benue rivers and their tributaries.

\subsubsection{Asa Dam and Eyenkorin, Kwara State}

The sample localities are located in Ilorin metropolis which is a Basement Complex terrain that has undergone deep weathering. The Nigeria Basement Complex is a group of igneous and metamorphic rocks of Precambrian age (Kogbe, 1975). It is largely undifferentiated and constitutes about $50 \%$ of the bedrock in Nigeria. Large outcrops of granite and gneisses with cross-cutting pegmatites are common (Alao, 1983). The general trend of the outcrops in the area is SW-NE with a west dip.

\section{MATERIALS AND METHODS}

\subsection{Site visit and Data collection}

Oko area in Anambra State, Agbaja Hill in Lokoja, Kogi State as well as Asa Dam and Eyenkorin (Ilorin metropolis) in Kwara State of Nigeria were visited for soil sampling and to evaluate existing conditions of slopes situated in the site. The weathered surface was removed and the outcrop was horizontally dug inward in order to obtain fresh samples. The effective soil sampling depth was determined using a screw soil auger, a surveying tape, depths of recent landslides and slope remodelling. However, in areas where landslides had occurred, the samples were collected from the sides of scar. In special cases, selection of sample locations were based on indications of slope instability, mainly soil creeping and cracking. Coordinates of the sampling pits (sites) and photographs were taken during field visits to provide additional records. The collected fresh soil samples were transported to the Mechanical Engineering Department's soil laboratory, University of Ilorin, Nigeria for geotechnical tests in order to access the probable mechanical behaviour. The investigated shear strength parameters of the soil samples were later used in slope stability evaluation. 
Nat. Hazards Earth Syst. Sci. Discuss., doi:10.5194/nhess-2016-297, 2016

\subsection{Geotechnical analysis}

Preliminary geotechnical classification and identification tests such as moisture content, bulk density, specific gravity, grain size distribution, hydraulic conductivity, particle density, bulk density, liquid limit, plastic limit, and plasticity index, compaction and shear strength tests were carried out on the soil samples based on the British Standard (BSI 1377:1990). Each geotechnical test was performed twice on the same soil sample under the same condition in order to determine the reliability of the geotechnical test results. The result of the Atterberg consistency limits were plotted after Seed et al. $(1983 ; 2003)$ in order to deduce whether the soils are susceptible to liquefaction. The boundaries in the gradation curves for soils susceptible to liquefaction, as proposed by Tsuchida (1970) were also used to determine whether the soils are susceptible to liquefaction.

\subsubsection{Grain Size Analysis}

Mechanical and hydrometer methods were used to determine the grain size distributions. The mechanical method (wet sieving) was employed in the analysis of particles that are greater than $0.075 \mathrm{~mm}$ in diameter. A calibrated (ASTM 152H) hydrometer was used to analyse the finer grains $(\mathrm{d}<0.075 \mathrm{~mm})$ in the laboratory.

\subsubsection{Procedures for mechanical method (wet sieving)}

The soil particles were gently separated from each other. The sieve set (stack of sieves) were arranged in descending order from the top with a retainer beneath it. $100 \mathrm{~g}$ of each soil sample was weighed and poured into the sieve stack. The soil filled sieve stack was placed on the mechanical sieve shaker for about 10 minutes. The sieve stack was later separated and the soil fraction retained by the mesh of each sieve was retrieved. The soil fraction retained by each sieve was weighed and the statistical data of the grain size analysis was computed.

\subsubsection{Procedures for hydrometer method}

The sieved clay and silt from the sieve washing was collected in a container and allowed to settle. The supernatant water was decanted and the mud residue was dried in the drying oven for about 24 hours. $500 \mathrm{~g}$ of the dried mud was soaked in distilled water for 24 hours and mixed properly in a stirrer with a dispersive agent (hexametaphosphate) added to avoid flocculation of the grains. The suspension was poured into 1 litre measuring cylinder and mixed before the soil grains were allowed to settle in the suspension. The hydrometer was later inserted into the water in the measuring cylinder and its reading was recorded periodically. As the settling proceeds, the hydrometer sinks deeper into the solution. The temperature at each hydrometer 
reading was recorded and then a statistical data sheet was produced showing the results of the analysis. The clay and silt percentage in the samples were then calculated from the graph obtained by plotting percentage passing against the grain diameters.

\subsubsection{Atterberg limits determination}

To determine the liquid limit of the soil samples, the fraction of the soil that passed through the $425 \mu \mathrm{m}$ sieve was weighed ( $230 \mathrm{~g}$ ) on a weighing balance and carefully mixed with clean water in order to form a thick homogeneous paste. A groove was cut through the paste (soil sample) that was placed inside the Casangrade's apparatus cup and the numbers of blows were counted and recorded until the groove in the soil closes. The moisture contents were determined and the moisture contents were plotted against the numbers of blows in order to determine the liquid limit. To determine the plastic limit, soil sample was also taken from the soil sample that passes through the $425 \mu \mathrm{m}$ sieve and weighed on the balance. Then it was thoroughly mixed with water using the hand until it becomes homogenous and plastic enough to form ellipsoidal-circular shape (i.e. ball). The ball-shaped soil was rolled in a rolling device until the thread cracks or crumbles at about $4 \mathrm{~mm}$ diameter. The crumbled sample $(4 \mathrm{~mm})$ was then air-dried thus the moisture contents were determined.

\subsubsection{Procedures for compaction test}

$3 \mathrm{~kg}$ of soil sample was weighed and poured into the mixing pan. $120 \mathrm{~cm}^{3}$ (4\%) of water was measured, added and mixed with the soil in the mixing pan using a hand trowel. The cylinder mould was placed on a base plate, then a representative specimen of the soil was put into the mould and compacted with 25 evenly distributed blows of the rammer. This represents the first layer. After the compaction, the volume of soil in the mould reduced, more soil specimen was added into the mould and compacted with another 25 evenly distributed blows. The extension collar was fixed unto the mould. This is mainly for the last layer and removed after the last layer was made and aided to achieve a smooth level surface. The mould was filled with more of the soil specimen and compacted to make the third layer. This is for standard Proctor, and five layers of the soil specimen with 55 evenly distributed blows of the rammer makes the modified Proctor. The mould with the soil was weighed and the soil was sampled at the top and bottom of the mould for water content and the dry density determination. The mould was emptied into the mixing pan and another $120 \mathrm{~cm}^{3}(4 \%)$ of water was added to the soil and mixed. The same procedure was repeated for all the samples. The dry densities were plotted against water contents for the standard Proctor and modified Proctor in order to determine the 
maximum dry densities (MDD) and optimum moisture contents (OMC) of the soil samples in each situation.

\subsubsection{Shear strength determination}

Two $3 \mathrm{~kg}$ of both soil samples (standard and modified Proctor for each soil sample) were weighed and mixed with the corresponding optimum moisture content. The soil samples were then compacted as described in the above procedure. A square sampler was then gently used to collect a representative sample. Each collected sample was placed in a shear box and a load was placed on it both in horizontal and vertical positions and the deformation dial gauges were set at zero. A set of normal loads of $5 \mathrm{~kg}, 10 \mathrm{~kg}, 15 \mathrm{~kg}$ and $20 \mathrm{~kg}$ were applied one after the other in successive tests. The readings on the load dial units were recorded, and the procedure was repeated for the standard Proctor and modified Proctor for other samples. The shear strength results were presented as stress-strain curves and the shear stress was plotted against the normal stress, thus the angle of cohesion and angle of internal friction were determined.

\subsection{Method of slices using SLOPE/W software}

The slope model was analysed using SLOPE/W and SEEP/W software with the aim of giving the state of the slopes with their factor of safety using Limit Equilibrium Method (LEM).The software computes the factor of safety (FOS) for various shear surfaces (SS), for example circular and non-circular. However, only the circular SS was automatically searched. The method of slices was considered in relation to its application to SLOPE/W and traditional methods of analysis. According to Abramson et al. (2002) slices method is widely used by much computer software because it can accommodate geometry of complex slope, different soil conditions and influence of external boundary loads. Conventionally, the weight of soil lying at a particular point should influence the stress acting normal to that point on sliding surface. Theoretically, the basic principle of slices method is the potential slide mass, which is subdivided into several vertical slices and the equilibrium of individual slice can be evaluated in terms of forces and moments. This would allow easy estimation of the allowable safety factor of a slide mass. In this study, two soil layers obtained from shear strength test, with different strength parameters were used for slope stability analyses. This same shear strength parameters were used in both dry and wet conditions. Similarly, two unit weight of soils, one above the groundwater table (GWT) and the other below the GWT were also considered. The complete set of input parameters used in the study are shown in Table 9. The three different conditions considered for slope stability analyses are dry slope, wet slope and dry slope with external loads. The analysed load conditions were defined as: 
- Case 1: Completely dry slope, i.e. no GWT inside the model,

- Case 2: Completely saturated slope, i.e. GWT on the surface (hydrostatic pore pressure),

- Case 3: Dry slope with external forces, i.e. $\mathrm{q}=40$ and $50 \mathrm{kPa}$.

The stability of the dry slope was first analysed in SLOPE/W. The minimum factor of safety (FOS), critical slip surfaces (CSS) were searched by entry and exit option as well as groundwater table (GWT) level shown in the model using limit equilibrium (LM) principle. The CSS was searched from thousands of possible SS by defining the input of 15 slices, 1500 iterations, 15 increments for entry, 10 increments for exit and 5 increments for radius. In addition to the limit equilibrium methods (LEM), the Bishop's and Janbu's simplified methods as well as the Spencer and Morgenstern-Price (M-P) factors of safety were used for rotational and irregular surface failure mechanisms.

\section{RESULTS AND DISCUSSION}

\subsection{Grain size distribution and soil classification}

The results of grain size analysis is shown in Figure 4 and Table 2. The grain size distribution curves show that the soil samples consist of all fractions ranging from gravely to clayey. The clay content is found between 2-34 \% in all the soil samples. The soil sample from Asa Dam road in Ilorin, which is plastic in nature has the highest clay content of about $34 \%$. Soil samples from Lokoja and Anambra states have very low fine content ranging from 2-12 \% and are not plastic in nature. The sand fraction dominated the samples (constituted about 70-80\% of the samples) especially those gotten from Lokoja and Anambra states. Similarly, the grading coefficient $(\mathrm{Cu}=$ D60/D10) varies from 5-275, except for the sample from Asa Dam 1 with $\mathrm{Cu}$ of 2000. Based on the Unified Soil Classification System (ASTM D2487-90, 1992), all the soil samples are classified as well graded with group symbols SW, SM and CL (Figures 4 and 5; Table 2).

\subsection{Atterberg limit}

The summary of results obtained from moisture content, liquid limit, plastic limit and plasticity index analyses are presented in Figure 6 and Table 3. The plasticity charts (Figure 7) was used to classify the samples and most of the samples are above A-line (Figure 8). Eyenkorin 1, 2 and Asa Dam 1, 2 are in the region with symbol CL, thus they are classified as inorganic clays of medium compressibility. Anambra 1, 2 and Lokoja 1, 2 and 3 falls in the CL-ML region and thus they are classified as cohesionless and inorganic silts of low compressibility. 
Nat. Hazards Earth Syst. Sci. Discuss., doi:10.5194/nhess-2016-297, 2016

\subsection{Compaction test}

The compaction test at standard state condition yielded maximum dry densities (MDD) of $1.84 \mathrm{~g} / \mathrm{cm}^{3}$ and $1.88 \mathrm{~g} / \mathrm{cm}^{3}$ for Eyenkorin 1 and 2, respectively (Figure 9). The optimum moisture content (OMC) for Eyenkorin (in Kwara state) 1 and 2 are $14.0 \%$ and $13 \%$, respectively. Samples from Lokoja (Kogi state) and Oko (Anambra state) have lower values of MDD and OMC, ranging between $1.64-1.80 \mathrm{~g} / \mathrm{cm}^{3}$ and $8.0-12.3 \%$, respectively. These values when compared to Table 4 show that the samples can be described as granular material with soil having anticipated embankments performance as poor to fair, value as subgrade material as fair to good and value as a base course as good to poor (Table 5).

\subsection{Shear strength and permeability}

The summary of shear strength and permeability results, as well as their interpretations are tabulated in Tables 6 and 7. The direct shear strength test on the soil samples show that the cohesion and angle of internal friction varies between $40-80 \mathrm{kPa}$ and $24-35^{\circ}$. The Coefficient of permeability of the soil samples vary between $8.71 \times 10^{-5}$ and $1.18 \times 10^{-3}$.

\subsection{Liquefaction susceptibility}

The results of liquefaction studies after Seed et al. $(1983 ; 2003)$ are depicted in Figures 10 and 11. Liquefaction involves the temporary loss of internal cohesion of material, such that it behaves as a viscous fluid rather than as a soil (Alexander, 1993). Soils containing a high percentage of sand and silt will deform more quickly than those containing high percentage of clay. Due to their cohesive strength, clays adjust more slowly to increase pore-water pressure than unconsolidated soils. The plot of plasticity index against Liquid limit after Seed et al. (2003) shows that the soil samples from Anambra and Lokoja are potentially liquefiable. The liquefaction screening criteria after Andrews and Martin (2000) also shows that Oko (Anambra), Eyenkorin (Kwara) and Lokoja (Kogi) are potentially susceptible to liquefaction, whereas samples from Asa Dam 1 - 2 (Kwara) are not susceptible to liquefaction (Figure 11).

Boundaries in the gradation curves for soils were used to determine liquefaction susceptibility of the soil samples (Tsuchida, 1970). Boundary most susceptible to liquefaction is in the sand region, with about $60-80 \%$ of sand, whereas boundary for potentially liquefiable soil is in the region of 20-40\% sand (Tsuchida, 1970). Soils with a higher percentage of gravels tend to mobilize higher strength during shearing, and to dissipate excess pore pressures more rapidly than sands. However, there are case histories indicating that liquefaction has occurred in loose gravelly soils (Seed, 1968; Ishihara, 1985; Andrus et al., 1991) during severe ground shaking 
Nat. Hazards Earth Syst. Sci. Discuss., doi:10.5194/nhess-2016-297, 2016

or when the gravel layer is confined by an impervious layer. Based on Tsuchida (1970) classification, it can be deduced that soil samples from Anambra 1and Lokoja 1-3 have \% of sand ranging from $72-96 \%$, thus they are liquefiable in nature (Figure 12; Table 8). Anambra 2 has $63 \%$ of sand which is potentially liquefiable, based on the classification proposed by Tsuchiba (1970). Some of the soil samples fall outside Tsuchida's boundaries and Walker and Steward (1989) documented that non-plastic and low plasticity silts, despite having their grain size distribution curves outside of Tsuchida's boundaries for soils susceptible to liquefaction, have a potential for liquefaction similar to that of sands. In addition, they further stated that increased plasticity will reduce the level of pore pressure response in silts. This reduction, however, is not significant enough to resist liquefaction for soils with plasticity indices of $\leq 5$.

\subsection{Landslide and slope stability}

Slope angles, slope length play important roles in the stability of slopes. The slope angle is regarded as the major topographic factor in determining stability. The physical characteristics of the terrain influencing slope instability were measured. The characteristics recorded included slope length, angles, and altitude. The slope angles can be classified as steep angle as they are close to $60-70^{\circ}$ in the study areas. Though the embankment slopes in Asa Dam area and Eyenkorin area have values in the range of $30-35^{\circ}$ and are classified as moderate angles.

The factor of safety (FOS) gotten from SLOPE/W software were used to classify the slopes into safe, state of impending failure and failed slopes. Several authors have proposed different values for slope classification. The general and acceptable value for stable slope is 1.5 , whereas a value less than 1 is always classified as unsafe. The analysed samples have values ranging from 1.366 - 2.488 (Figure 13-19; Table 10). The value of 1.366 is from the Oko area in Anambra state where landslide occurred. The maximum value of 2.488 was obtained at Asa Dam, which is an embankment slope and it depicts stable slope. The FOS for dry slope was higher when compared to the FOS values from wet slope (Figure 13). This was due to the effect of pore water pressure on the soil as it reduced the shear strength of the soil. Figure 14 shows the critical slip surface (CSS) and factor of safety (FOS) for non-optimised wet slope. The slip surface was at the top of the slope (Figure 13a) whereas in Figure 13b, it shows the CSS passing through ground water table (GWT), thus making the slip surface size bigger and occupies all of the entry point. Since suction effect has not been considered in the analysis, the located GWT has serious effect on the FOS. Figure 14 shows an increased in the geometry, and the CSS and FOS was affected drastically. The reduction in FOS from 2.51 to 1.45 (Figure 13) is an indication of the effect of pore water pressure and gravity on the failed site. Limit 
equilibrium methods computed the values of FOS slightly lower than 1.5 which depict instability. The pore pressure at the toe causes reduction in the effective normal stresses, and hence the shear strength.

Two of the primary assumptions of Bishop's simplified method ignores interslice shear forces and satisfies only moment equilibrium. However, not considering shear forces in the General Limit Equilibrium (GLE) terminology mean that lambda $(\lambda)$ is zero. As a result, the Bishop's Simplified factor of safety falls on the moment curve in Figure 17 where lambda is zero. Janbu's Simplified method also ignores interslice shear forces and only satisfies force equilibrium. The Janbu's Simplified factor of safety consequently falls on the force curve in Figure 17 where $\lambda$ is zero. The Spencer and Morgenstern-Price (M-P) factors of safety are determined at the point where the two curves cross. At this point the factor of safety satisfies both moment and force equilibrium. Whether the crossover point is the Spencer or M-P factor of safety depends on the interslice force function. Spencer only considered a constant X/E ratio for all slices, which in the GLE formulation corresponds to a constant (horizontal) interslice force function.

\section{CONCLUSION}

Liquefaction was suspected as the main cause of the landslide that occurred in Oko area of Anambra State. The results from gradation curve which gave over $80 \%$ sand for the samples from Lokoja and Anambra suggested that liquefaction is possible in the area if necessary vibration is generated either from blasting or trucks/vehicular movement. In addition, from the satellite image, the terrain is rugged in nature and the slope is steep which can facilitate landslide by gravity. The results from the Atterberg limits show mixed values and therefore making it difficult to use the values in the liquefaction interpretation. The liquefaction effects on the soils has been proven to be one of the strong factors in the failure of these sites especially the site at Oko area in Anambra State. With necessary vibration, liquefaction in those sites could be a serious issues because of the composition of the grains (70-90\%) sand and low plasticity. The FOS values for Anambra 1-2, Lokoja 1-3, Eyenkorin 1-2 and Asa Dam 1-2 are $1.452,1.946,2.196$ and 2.488 , respectively. These values indicate stability but care must be taken as the condition at the site shows that the slope is in its state of impending failure. Optimisation effects was also tried and the results shown that loads on these slope might contribute to the failure of the slopes. 
Nat. Hazards Earth Syst. Sci. Discuss., doi:10.5194/nhess-2016-297, 2016

Manuscript under review for journal Nat. Hazards Earth Syst. Sci.

Published: 26 October 2016

(c) Author(s) 2016. CC-BY 3.0 License.

\section{AUTHOR CONTRIBUTION}

Dr Omoniyi Ige supervised the field work and writing of the manuscript. Tolulope Oyeleke and Temitope Oloniniyi carried out the fieldwork. Christopher Baiyegunhi carried out data processing and writing of the manuscript, while Luzuko Sigabi was involved in data processing and correction of manuscript.

\section{ACKNOWLEDGEMENT}

The authors wish to thank Mr Ojuola Raymond of Rafworld Geological Services Limited, Abuja, Nigeria for accommodation and assistance during fieldwork.

\section{CONFLICT OF INTERESTS}

The authors declared that there are no conflicts of interest concerning the publication of this research work.

\section{REFERENCES}

Alao, D.A., 1983. Geology and Engineering properties of laterites from Ilorin, Nigeria" Engineering Geology Vol. 20, pp. 111 - 118.

Abramson, L. W., Lee, T. S., Sharma, S. and Boyce, G. M., 2002. Slope stability and stabilization methods, 2nd ed., John Wiley and Sons, Inc., New York, 712 p.

Alexander, D. (1993). Natural Disaster, London, University College Library Press.

Ako T. A., Abba F. M., Onoduku S., Nuhu W. M., Alabi A. A. and Mamodu A., 2014. The October 13, 2010 Landslides on the Azenge Mountain in Imande Ukusu, Nkomon Disrict, Benue State, Nigeria Environment and Ecology Research Vol. 2, (3), 113-121.

American Association of State Highway and Transportation Officials (AASHTO). AASHTO M145-91, 2003. Standard Specifications for Classification of Soils and Soil-Aggregate Mixtures for Highway Construction Purposes.

American Society for Testing Materials, ASTM, 1992. Standard test method for classification of soils for engineering purposes (Unified Soil Classification System).

ASTM standard D2487-90, 1992. Annual Books of ASTM Standards, Vol. 04.08, sec. 4. American Society for Testing and Materials (ASTM), Philadelphia, Penn. pp. 326-336.

American Society for Testing Materials, ASTM, 1557, 1991. Test Method for Laboratory Compaction Characteristics of Soil Using Modified Effort. ASTM D 1557-91 Standard Test Method for Laboratory Compaction Characteristics of Soil Using Modified Effort. Annual Book of ASTM Standards. 
Nat. Hazards Earth Syst. Sci. Discuss., doi:10.5194/nhess-2016-297, 2016

Manuscript under review for journal Nat. Hazards Earth Syst. Sci.

Published: 26 October 2016

(c) Author(s) 2016. CC-BY 3.0 License.

Andrus, R. D., Stokoe, K. H., and Roesset, J. M., 1991. Liquefaction of Gravelly Soil at Pence Ranch during the 1983 Borah Peak, Idaho Earthquake. First International Conference on Soil Dynamics and Earthquake Engineering V, Karlsruhe, Germany.

Andrews, D. C. A. and Martin, G. R., 2000. Criteria for liquefaction of silty soils, Proceedings of the 12th World Conference on Earthquake Engineering, New Zealand, Paper No. 0312 .

Annor, A.E., 1998. Structural and chronology relationship between low grade Igarra schist terrain in the Precambrian exposure of Southwestern Nigeria" Journal of mining and geology. Vol. 32, No. 2, pp. 187-194.

Ashiru M. A., Jacob E. S. and Sule M., 2014. Slope Stability Analysis Using Computer Software for Black Cotton Soil of North - Eastern Nigeria. J. of Sciences and Multidisciplinary Research, 6 (2) $60-77$.

Black, R., 1980. Precambrian of West Africa. Episodes 4:3-8.

British Standard Institution, 1990. Methods of Test for Soils for Civil Engineering Properties (BS 1377)" British Standard Institution: London, UK. 143p.

Bromhead, E.N., 1987. Slopes and embankment. In P. Attewell and R. Taylor (eds).

Ground movements and their effects on structures, Glass glow, Survey University Press, Blackie Group.

Burke, K. C, and Dewey, J. F., 1972. Orogeny in Africa. In: Dessauvagie TFJ, Whiteman AJ (eds), Africa geology. University of Ibadan Press, Ibadan, 583-608.

Casagrande, A., and Fadum, R.E., 1936. Notes on Soil Testing for Engineering Purposes, Soil Mechanics Series, Graduate School of Engineering, Harvard University, Cambridge. M.A., 8, 567.

Crozier M. J., 1984. Field Assessment of Slope Instability in D Brunsden and D Prior (eds). Slope Instability, New York, John Wiley and Sons.

Dada, S. S., 2006. Proterozoic evolution of Nigeria. In: Oshi O (ed) The basement complex of Nigeria and its mineral resources (A Tribute to Prof. M. A. O. Rahaman). Akin Jinad \& Co. Ibadan, 29-44.

Duncan, J. M., 1996. State of the Art: Limit Equilibrium and Finite Element Analysis in Slopes. Journal of Geotechnical Engineering, Vol. 122 No. 7, 577-96. 
Nat. Hazards Earth Syst. Sci. Discuss., doi:10.5194/nhess-2016-297, 2016

Manuscript under review for journal Nat. Hazards Earth Syst. Sci.

Published: 26 October 2016

(c) Author(s) 2016. CC-BY 3.0 License.

Ishihara, K., 1985. Stability of natural deposits during earthquakes. Proceedings of the Eleventh International Conference on Soil Mechanics and Foundation Engineering, San Francisco.

Knapen, J. K, Poesen M, Brengelmans, J; Deckers W. J. and Muwanga, A. (2006). Landslides in Densely Populated County at the Foot Slopes of Mount Elgon (Uganda): Characteristics and Causal Factors, Geomorphology 73, 149-165.

Kogbe C.A., 1975. The cretaceous and Precambrian basement sediments of southwestern Nigeria in Kogbe C.A (ed). Geology of Nigeria, 2nd revised edition

Matsushi, Y. Hattanji, T. and Matsukura, Y., 2006. Mechanics of Shallow Landslides on Soil Mantled Slopes with Permeable and Impermeable Bedrock in Boso Peninsula, Japan, Geomorphology 76, 92 -108.

McCall, G.J.H., Laming, D.J.C. and Scott, S.C., 1992. Geohazards. Natural and Man-Made. Chapman and Hall, London.

National Research Council, 1985. Liquefaction of soils during earthquakes. Committee on Earthquake Engineering, National Research Council, National Academy Press, Washington, D.C.

Nguimbous-Kouoh, J.J., Takougang, E.M.T. Nouayou, R., Tabod, C.T. and ManguelleDicoum, E., 2012. Structural Interpretation of the Mamfe Sedimentary Basin of Southwestern Cameroon along the Manyu River Using Audiomagnetotellurics Survey. ISRN Geophysics. pp. 1-7. http://dx.doi.org/10.5402/2012/41304.

Ngecu, M. and Mathu, E.M., 1999. The El-Nino Triggered Landslides and Their SocioEconomic Impact on Kenya. Environmental Geology 38, 277 - 284.

Obaje N.G., 2009. Geology and Mineral Resources of Nigeria. Springer-Verlag Berlin Heidelberg, 219p.

Okogbue, C.O., 1992. The 1988 Nanka landslide, Anambra State, Nigeria, Bull. Int. Assoc. Eng. Geol. 46: 79 - 87.

Rahaman M.A., 1976. Review of the Basement Geology of South-Western Nigeria,” In: Kogbe CA (ed) Geology of Nigeria, 2nd ed., Elizabethan Publishers, Lagos, pp. 41-58.

Seed, H. B., 1968. Landslides during earthquakes. Journal of the soil mechanics and foundations division, ASCE, Vol. 94, No. SM5.

Seed, H. B., Idriss, I. M., and Arango, I., 1983. Evaluation of Liquefaction Potential Using Field Performance Data," Journal of the Geotechnical Engineering Division, ASCE, Vol. 109, No. GT3. 
Nat. Hazards Earth Syst. Sci. Discuss., doi:10.5194/nhess-2016-297, 2016

Manuscript under review for journal Nat. Hazards Earth Syst. Sci.

Published: 26 October 2016

(c) Author(s) 2016. CC-BY 3.0 License.

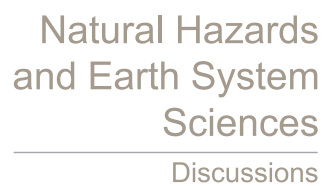

(c) (1)

Seed, R. B., Cetin, K. O., Moss, R. E. S., Kammerer, A. M., Wu, J., Pestana, J. M., Riemer, M.F., Sancio, R. B., Bray, J. D., Kayen, R. E., Faris, A., 2003. Recent Advances in Soil Liquefaction Engineering: A Unified and consistent framework, 26th Annual ASCE Keynote Presentation, 71.

Tsuchida H., 1970. Prediction and countermeasure against the liquefaction in sand deposits. Seminar Abstract In: Port Harbour Research Institute, 3.1-3.33.

Varnes, D.J., 1984. Slope Movement and Types and Process; In Schuster, R.L. and Krizek, R.J. (eds), Landslides: Analysis and Control, Transportation Research Board Special Report 176, National Academy of Sciences, Washington D.C.

Walker, A.J., and Steward, H.E., 1989. Cyclic undrained behaviour of nonplastic and low plasticity silts," Technical Report NCEER-89-0035, National Center for Earthquake Engineering Research, SUNY at Buffalo. 
Nat. Hazards Earth Syst. Sci. Discuss., doi:10.5194/nhess-2016-297, 2016

Manuscript under review for journal Nat. Hazards Earth Syst. Sci.

Published: 26 October 2016

(c) Author(s) 2016. CC-BY 3.0 License.

512 Table 1: Causes of landslides (After McCall, 1992).

\begin{tabular}{|c|c|}
\hline External Causes & Internal Causes \\
\hline $\begin{array}{l}\text { 1. Geometrical change } \\
\text { - Height } \\
\text { - Gradient } \\
\text { - Slope length }\end{array}$ & $\begin{array}{l}\text { 1. Progressive Failure (internal response to unloading) } \\
\text { - Expansion and swelling } \\
\text { - Fissuring } \\
\text { - Straining, softening } \\
\text { - Stress concentration }\end{array}$ \\
\hline $\begin{array}{l}\text { 2. Loading } \\
\text { - Natural } \\
\text { - Man-induced }\end{array}$ & $\begin{array}{l}\text { 2. Weathering } \\
\text { - Physical property changes } \\
\text { - Chemical changes }\end{array}$ \\
\hline $\begin{array}{l}\text { 3. Unloading } \\
\text { - Natural } \\
\text { - Man-induced }\end{array}$ & $\begin{array}{l}\text { 3. Seepage erosion } \\
\text { - Removal of cements } \\
\text { - Removal of fine particles }\end{array}$ \\
\hline $\begin{array}{l}\text { 4. Vibrations } \\
\text { - Single } \\
\text { - Multiple/Continuous }\end{array}$ & $\begin{array}{l}\text { 4. Water regime change } \\
\text { - Saturation } \\
\text { - Rise in water table } \\
\text { - Excess pressures } \\
\text { - Draw down }\end{array}$ \\
\hline
\end{tabular}

Table 2: Summary of the grain size analysis and soil classification.

\begin{tabular}{|c|c|c|c|c|c|c|c|c|c|}
\hline Sample ID & S.G & $\begin{array}{l}\% \\
\text { clay }\end{array}$ & $\begin{array}{l}\% \\
\text { silt }\end{array}$ & $\begin{array}{l}\% \\
\text { fine }\end{array}$ & $\begin{array}{l}\% \\
\text { sand }\end{array}$ & $\begin{array}{l}\% \\
\text { gravel }\end{array}$ & $\mathrm{Cu}$ & $\mathrm{Cc}$ & $\begin{array}{l}\text { Group } \\
\text { symbol }\end{array}$ \\
\hline Lokoja 1 & 2.53 & 2 & 2 & 4 & 96 & 0 & 5 & 1.19 & SW \\
\hline Lokoja 2 & 2.78 & 8 & 10 & 18 & 80 & 2 & 12 & 0.0005 & SM \\
\hline Lokoja 3 & 2.56 & 12 & 8 & 20 & 72 & 2 & 389 & 81 & SM \\
\hline Anambra 1 & 2.58 & 6 & 5 & 11 & 83 & 6 & 86 & 38 & SM \\
\hline Anambra 2 & 2.47 & 12 & 18 & 30 & 63 & 7 & 267 & 6 & SM \\
\hline Eyenkorin 1 & 2.67 & 18 & 35 & 55 & 31 & 16 & 220 & 7 & CL \\
\hline Eyenkorin 2 & 2.68 & 22 & 39 & 61 & 31 & 8 & 33 & 0.42 & CL \\
\hline Asa Dam 1 & 2.65 & 32 & 18 & 50 & 30 & 20 & 2000 & 0.035 & $\mathrm{CL}$ \\
\hline Asa Dam 2 & 2.65 & 34 & 26 & 60 & 36 & 4 & 275 & 0.074 & $\mathrm{CL}$ \\
\hline
\end{tabular}

Key: SW and SM = Poorly Graded Sand, CL= Well Graded Sandy silt. 
Nat. Hazards Earth Syst. Sci. Discuss., doi:10.5194/nhess-2016-297, 2016

Manuscript under review for journal Nat. Hazards Earth Syst. Sci.

Published: 26 October 2016

(c) Author(s) 2016. CC-BY 3.0 License.
Natural Hazards

and Earth System

Sciences

518 Table 3: Plasticity values of the soil samples.

\begin{tabular}{|c|c|c|c|c|c|}
\hline Sample ID & $\begin{array}{c}\text { Depth } \\
(\mathrm{m})\end{array}$ & $\begin{array}{c}\text { Moisture } \\
\text { content }(\%)\end{array}$ & $\begin{array}{c}\text { Liquid limit } \\
(\%)\end{array}$ & $\begin{array}{c}\text { Plastic limit } \\
(\%)\end{array}$ & $\begin{array}{c}\text { Plasticity } \\
\text { index (\%) }\end{array}$ \\
\hline Lokoja 1 & 8.6 & 1.6 & 23.0 & 15.0 & 8.0 \\
\hline Lokoja 2 & 12.5 & 0.8 & 28.0 & 24.0 & 4.0 \\
\hline Lokoja 3 & 17.0 & 9.8 & 27.0 & 18.0 & 9.0 \\
\hline Anambra 1 & 10.2 & 0.8 & 21.0 & 16.5 & 3.5 \\
\hline Anambra 2 & 12.0 & 0.8 & 23.0 & 19.45 & 19.7 \\
\hline Eyenkorin 1 & 2.3 & 1.3 & 41.0 & 21.3 & 29.0 \\
\hline Eyenkorin 2 & 3.0 & 1.8 & 44.5 & 15.5 & 22.5 \\
\hline Asa Dam 1 & 2.5 & 2.5 & 40.0 & 17.5 & 19.5 \\
\hline Asa Dam 2 & 3.4 & 3.3 & 43.0 & 22.5 & \\
\hline
\end{tabular}

519

520

521

Table 4: Compaction characteristics and ratings of unified soil classification classes for soil construction (ASTM, 1557-91).

\begin{tabular}{|c|c|c|c|c|c|}
\hline $\begin{array}{c}\text { Visual } \\
\text { Description }\end{array}$ & $\begin{array}{l}\text { Maximum } \\
\text { Dry-Weight } \\
\text { Range } \\
\left(\mathrm{g} / \mathrm{cm}^{3}\right)\end{array}$ & $\begin{array}{l}\text { Optimum } \\
\text { Moisture } \\
\text { Range } \\
(\%)\end{array}$ & $\begin{array}{l}\text { Anticipated } \\
\text { Embankment } \\
\text { Performance }\end{array}$ & $\begin{array}{l}\text { Value as } \\
\text { Subgrade } \\
\text { material }\end{array}$ & $\begin{array}{l}\text { Value as } \\
\text { Base Course }\end{array}$ \\
\hline $\begin{array}{c}\text { Granular } \\
\text { material }\end{array}$ & $2.00-2.27$ & $7-15$ & $\begin{array}{l}\text { Good to } \\
\text { excellent }\end{array}$ & Excellent & Good \\
\hline $\begin{array}{c}\text { Granular } \\
\text { material } \\
\text { with soil }\end{array}$ & $1.76-2.16$ & $9-18$ & Fair to excellent & Good & Fair to poor \\
\hline $\begin{array}{c}\text { Fine sand } \\
\text { and sand }\end{array}$ & $1.76-1.84$ & $9-15$ & Fair to good & Good to fair & Poor \\
\hline $\begin{array}{c}\text { Sandy silts } \\
\text { and silts }\end{array}$ & $1.52-2.08$ & $10-20$ & Poor to good & Fair to poor & Not suitable \\
\hline $\begin{array}{c}\text { Elastic silts } \\
\text { and clays }\end{array}$ & $1.36-1.60$ & $20-35$ & unsatisfactory & Poor & Not suitable \\
\hline Silty-clay & $1.52-1.92$ & $10-30$ & Poor to good & Fair to poor & Not suitable \\
\hline $\begin{array}{c}\text { Elastic silty } \\
\text { clay }\end{array}$ & $1.36-1.60$ & $20-35$ & unsatisfactory & Poor to very & Not suitable \\
\hline \begin{tabular}{c} 
Clay \\
\hline
\end{tabular} & $90-115$ & $15-30$ & Poor to fair & Very poor & Not suitable \\
\hline
\end{tabular}


Nat. Hazards Earth Syst. Sci. Discuss., doi:10.5194/nhess-2016-297, 2016

Manuscript under review for journal Nat. Hazards Earth Syst. Sci.

Published: 26 October 2016

(c) Author(s) 2016. CC-BY 3.0 License.
Natural Hazards

and Earth System

Sciences

Discussions

522 Table 5: Compaction characteristics and ratings of the soil samples based on the unified soil

523 classification classes for soil construction (ASTM, 1557-91).

524

525

526

527

528

529

530

\begin{tabular}{|l|l|l|l|l|l|}
\hline Sample ID & $\begin{array}{l}\text { MDD } \\
\left(\mathrm{g} / \mathrm{cm}^{3}\right)\end{array}$ & $\begin{array}{l}\text { OMC } \\
(\%)\end{array}$ & $\begin{array}{l}\text { Anticipated } \\
\text { Embankment } \\
\text { Performance }\end{array}$ & $\begin{array}{l}\text { Value as } \\
\text { Subgrade material }\end{array}$ & $\begin{array}{l}\text { Value as Base } \\
\text { Course }\end{array}$ \\
\hline Lokoja 1 & 1.73 & 8.5 & Poor & Fair & Good \\
\hline Lokoja 2 & 1.80 & 8.0 & Fair & Good & Poor \\
\hline Lokoja 3 & 1.76 & 12.3 & Fair & Good & Poor \\
\hline Anambra 1 & 1.76 & 10.1 & Fair & Good & Poor \\
\hline Anambra 2 & 1.64 & 8.8 & Poor & Good & Fair \\
\hline Eyenkorin 1 & 1.84 & 14.0 & Fair & Good & Fair \\
\hline Eyenkorin 2 & 1.88 & 13.0 & Fair & Good & Fair \\
\hline Asa Dam 1 & 1.85 & 13.4 & Fair & Good & Fair \\
\hline Asa Dam 2 & 1.87 & 12.2 & Fair & Good & Fair \\
\hline
\end{tabular}

Table 6: The summary of the shear strength parameters and interpretation.

\begin{tabular}{|c|c|c|c|}
\hline Sample ID & $\begin{array}{c}\text { Cohesion, c } \\
(\mathrm{kPa})\end{array}$ & $\begin{array}{c}\text { Angle of internal } \\
\text { friction, } \varphi\end{array}$ & Interpretation \\
\hline Lokoja 1 & 48 & $28.5^{0}$ & Loose sand: rounded grains \\
\hline Lokoja 2 & 70 & $29^{0}$ & Loose sand: rounded grains \\
\hline Lokoja 3 & 65 & $24^{0}$ & Loose sand: rounded grains \\
\hline Anambra 1 & 50 & $29^{0}$ & Loose sand: rounded grains \\
\hline Anambra 2 & 55 & $28^{0}$ & Loose sand: rounded grains \\
\hline Eyenkorin 1 & 60 & $23^{0}$ & Loose sand: rounded grains \\
\hline Eyenkorin 2 & 80 & $26^{0}$ & Loose sand: rounded grains \\
\hline Asa Dam 1 & 40 & $35^{0}$ & Medium sand: rounded grains \\
\hline Asa Dam 2 & 60 & $32^{0}$ & Medium sand: rounded grains \\
\hline
\end{tabular}


Nat. Hazards Earth Syst. Sci. Discuss., doi:10.5194/nhess-2016-297, 2016

Manuscript under review for journal Nat. Hazards Earth Syst. Sci.

Published: 26 October 2016

(c) Author(s) 2016. CC-BY 3.0 License.

531 Table 7: Coefficient of permeability for the samples and their interpretations.

\begin{tabular}{|l|l|l|l|l|}
\hline Sample ID & $\boldsymbol{K}(\mathbf{m m} / \mathbf{s e c})$ & $\boldsymbol{K}(\mathbf{c m} / \mathbf{s e c})$ & Interpretation & $\begin{array}{l}\text { Drainage } \\
\text { condition }\end{array}$ \\
\hline Lokoja 1 & $1.18 \times 10^{-3}$ & $1.18 \times 10^{-4}$ & Clean sand and gravel mixtures & Good \\
\hline Lokoja 2 & $9.77 \times 10^{-4}$ & $9.77 \times 10^{-5}$ & Very fine sand & Poor \\
\hline Lokoja 3 & $3.61 \times 10^{-4}$ & $3.61 \times 10^{-5}$ & Very fine sand & Poor \\
\hline Anambra 1 & $8.71 \times 10^{-4}$ & $8.71 \times 10^{-5}$ & Very fine sand & Poor \\
\hline Anambra 2 & $7.80 \times 10^{-4}$ & $7.80 \times 10^{-5}$ & Very fine sand & Poor \\
\hline Eyenkorin 1 & $1.18 \times 10^{-3}$ & $1.18 \times 10^{-3}$ & Clean sand and gravel mixtures & Good \\
\hline Eyenkorin 2 & $1.18 \times 10^{-3}$ & $1.18 \times 10^{-3}$ & Clean sand and gravel mixtures & Good \\
\hline Asa Dam 1 & $1.18 \times 10^{-3}$ & $1.18 \times 10^{-3}$ & Clean sand and gravel mixtures & Good \\
\hline Asa Dam 2 & $1.18 \times 10^{-3}$ & $1.18 \times 10^{-3}$ & Clean sand and gravel mixtures & Good \\
\hline
\end{tabular}

Table 8: Grain size distribution summary showing the $\%$ of the grain fractions.

\begin{tabular}{|l|l|l|l|l|l|l|l|}
\hline Sample ID & $\begin{array}{l}\text { Specific } \\
\text { gravity }\end{array}$ & $\begin{array}{l}\% \\
\text { clay }\end{array}$ & $\begin{array}{l}\% \\
\text { silt }\end{array}$ & $\begin{array}{l}\% \\
\text { fines }\end{array}$ & $\begin{array}{l}\% \\
\text { sand }\end{array}$ & $\begin{array}{l}\text { Classification after } \\
\text { gravel } \\
\text { Tsuchiba (1970) }\end{array}$ \\
\hline Lokoja 1 & 2.53 & 2 & 2 & 4 & 96 & 0 & Liquefiable \\
\hline Lokoja 2 & 2.78 & 8 & 10 & 18 & 80 & 2 & Liquefiable \\
\hline Lokoja 3 & 2.56 & 12 & 8 & 20 & 72 & 2 & Liquefiable \\
\hline Anambra 1 & 2.58 & 6 & 5 & 11 & 83 & 6 & Liquefiable \\
\hline Anambra 2 & 2.47 & 12 & 18 & 30 & 63 & 7 & Potentially liquefiable \\
\hline Eyenkorin 1 & 2.67 & 18 & 35 & 55 & 31 & 16 & Potentially liquefiable \\
\hline Eyenkorin 2 & 2.68 & 22 & 39 & 61 & 31 & 8 & Potentially liquefiable \\
\hline Asa Dam 1 & 2.65 & 32 & 18 & 50 & 30 & 20 & Potentially liquefiable \\
\hline Asa Dam 2 & 2.65 & 34 & 26 & 60 & 36 & 4 & Potentially liquefiable \\
\hline
\end{tabular}


Nat. Hazards Earth Syst. Sci. Discuss., doi:10.5194/nhess-2016-297, 2016

Manuscript under review for journal Nat. Hazards Earth Syst. Sci.

Published: 26 October 2016

(c) Author(s) 2016. CC-BY 3.0 License.
Natural Hazards

542 Table 9: Input parameters used in SLOPE/W analyses.

543

\begin{tabular}{|c|c|c|c|c|}
\hline Location & Soil layer & $\mathrm{C}(\mathrm{kPa})$ & Phi $\left({ }^{\circ}\right)$ & $\gamma\left(\mathrm{kN} / \mathrm{m}^{3}\right)$ \\
\hline Oko1 (Anambra state) & Upper & 50 & 29 & 16.30 \\
\hline Oko 2 (Anambra state) & Lower & 55 & 28 & 15.70 \\
\hline Lokoja 1 (Kogi state) & Upper & 48 & 28.5 & 16.40 \\
\hline Lokoja 2 (Kogi state) & Middle & 70 & 29 & 17.10 \\
\hline Lokoja 3 (Kogi state) & Lower & 65 & 24 & 15.50 \\
\hline Eyenkorin 1 (Kwara state) & Upper & 70 & 26 & 14.21 \\
\hline Eyenkorin 2 (Kwara state) & Lower & 90 & 27 & 14.70 \\
\hline Asa Dam 1 (Kwara state) & Upper & 40 & 35 & 14.70 \\
\hline Asa Dam 2 (Kwara state) & Lower & 60 & 32 & 15.48 \\
\hline
\end{tabular}

544

545

546

547

Table 10: Summary of the factor of safety (FOS) for the soil samples.

\begin{tabular}{|l|l|l|l|l|l|l|l|l|l|}
\hline & \multicolumn{2}{|c|}{ O.D } & \multicolumn{2}{|c|}{ B.M } & \multicolumn{2}{c|}{ J.M } & \multicolumn{2}{l|}{ M.P } & FOS \\
\hline & M & F & M & F & M & F & M & F & M \\
\hline Anambra 1 and 2 & 1.366 & & 1.396 & - & - & 1.434 & 1.452 & 1.462 & 1.452 \\
\hline Lokoja 1 and 2 & 1.885 & & 1.951 & - & - & 1.883 & 1.946 & 1.950 & 1.946 \\
\hline Eyenkorin 1 and 2 & 2.430 & & 2.489 & - & - & 2.462 & 2.488 & 2.485 & 2.196 \\
\hline Asa Dam 1 and 2 & 2.118 & & 2.200 & - & - & 2.112 & 2.196 & 2.201 & 2.488 \\
\hline
\end{tabular}

$\mathrm{M}=$ Moment, $\mathrm{F}=$ Force, O.D = Ordinary method, B.M = Bishop method, J.M = Janbu method, M.P $=$ Morgestein price. 
Nat. Hazards Earth Syst. Sci. Discuss., doi:10.5194/nhess-2016-297, 2016

Manuscript under review for journal Nat. Hazards Earth Syst. Sci.

Published: 26 October 2016

(c) Author(s) 2016. CC-BY 3.0 License.

562 Table 11: Summary of the reviewed literatures on slope stability and landslide.

\begin{tabular}{|c|c|c|c|c|}
\hline Authors & Locality & Methodology & Research Interest & Findings \\
\hline $\begin{array}{l}\text { Okogbue, } \\
1992\end{array}$ & $\begin{array}{l}\text { Nanka, } \\
\text { Anambra } \\
\text { State }\end{array}$ & $\begin{array}{l}\text { Geotechnical } \\
\text { studies }\end{array}$ & $\begin{array}{l}\text { Causes of } 1988 \\
\text { Nanka landslide }\end{array}$ & $\begin{array}{l}\text { Over consolidation of } \\
\text { very highly plastic } \\
\text { mudstone layer }\end{array}$ \\
\hline $\begin{array}{l}\text { Ashiru et } \\
\text { al., } 2014\end{array}$ & $\begin{array}{l}\text { Nasarawa } \\
\text { Northeastern } \\
\text { Nigeria }\end{array}$ & $\begin{array}{l}3 \text { LEMs: } \\
\text { Stability chart, } \\
\text { SLOPE/W and } \\
\text { traditional } \\
\text { methods }\end{array}$ & $\begin{array}{l}\text { Stability of slopes on } \\
\text { Black Cotton Soils }\end{array}$ & $\begin{array}{l}\text { Dry- stable } \\
\text { Wet- unstable }\end{array}$ \\
\hline $\begin{array}{l}\text { Ako et al., } \\
2014\end{array}$ & $\begin{array}{l}\text { Nkomon } \\
\text { District } \\
\text { Benue State }\end{array}$ & $\begin{array}{l}\text { Interview, Field } \\
\text { observation and } \\
\text { Laboratory } \\
\text { studies }\end{array}$ & $\begin{array}{l}\text { Causes of Nov. } 13^{\text {th }} \text {, } \\
2010 \text { landslide in } \\
\text { Azenge Mountain in } \\
\text { Imande Ukusu, } \\
\text { Benue State }\end{array}$ & $\begin{array}{l}\text { Highly fractured } \\
\text { gneisses, granite and } \\
\text { basaltic rocks and } 2 \\
\text { grains type. Also, } \\
\text { other causes are } \\
\text { geological, } \\
\text { morphological and } \\
\text { human factors } \\
\text { contributed }\end{array}$ \\
\hline $\begin{array}{l}\text { Ogbonnaya, } \\
2015\end{array}$ & $\begin{array}{l}\text { Southeastern } \\
\text { Nigeria }\end{array}$ & $\begin{array}{l}\text { Geotechnical } \\
\text { studies }\end{array}$ & $\begin{array}{l}\text { Differentiation } \\
\text { between landslides } \\
\text { from sedimentary } \\
\text { and metamorphic } \\
\text { terrain }\end{array}$ & $\begin{array}{l}\text { Sedimentary terrain- } \\
\text { shallow volume } \\
\text { movement, material } \\
\text { slumps and short run } \\
\text { out Metamorphic } \\
\text { terrain- complex } \\
\text { translational and } \\
\text { rotational landslide }\end{array}$ \\
\hline This study & $\begin{array}{l}\text { Oko in } \\
\text { Anambra } \\
\text { state, Lokoja } \\
\text { in Kogi state, } \\
\text { and Asa dam } \\
\text { and } \\
\text { Eyenkorin } \\
\text { both in Kwara } \\
\text { state, Nigeria }\end{array}$ & $\begin{array}{l}\text { Field } \\
\text { observation, } \\
\text { geotechnical } \\
\text { studies and } \\
\text { SLOPE/W }\end{array}$ & $\begin{array}{l}\text { Evaluating } \\
\text { liquefaction } \\
\text { potential, causes of } \\
\text { landslide and degree } \\
\text { of slope stability }\end{array}$ & $\begin{array}{l}\text { Soil samples from } \\
\text { Anambra and Kogi are } \\
\text { potentially liquefiable, } \\
\text { whereas those from } \\
\text { Kwara are not } \\
\text { susceptible to } \\
\text { liquefaction. } \\
\text { The factor of safety } \\
\text { (FOS) values shows } \\
\text { that the slope is in its } \\
\text { state of impending } \\
\text { failure. } \\
\text { Liquefaction is } \\
\text { inferred as the main } \\
\text { cause of the landslide } \\
\text { in the areas. }\end{array}$ \\
\hline
\end{tabular}


Nat. Hazards Earth Syst. Sci. Discuss., doi:10.5194/nhess-2016-297, 2016

Manuscript under review for journal Nat. Hazards Earth Syst. Sci.

Published: 26 October 2016

(c) Author(s) 2016. CC-BY 3.0 License.
Natural Hazards and Earth System Sciences

Discussions

(c) (i)
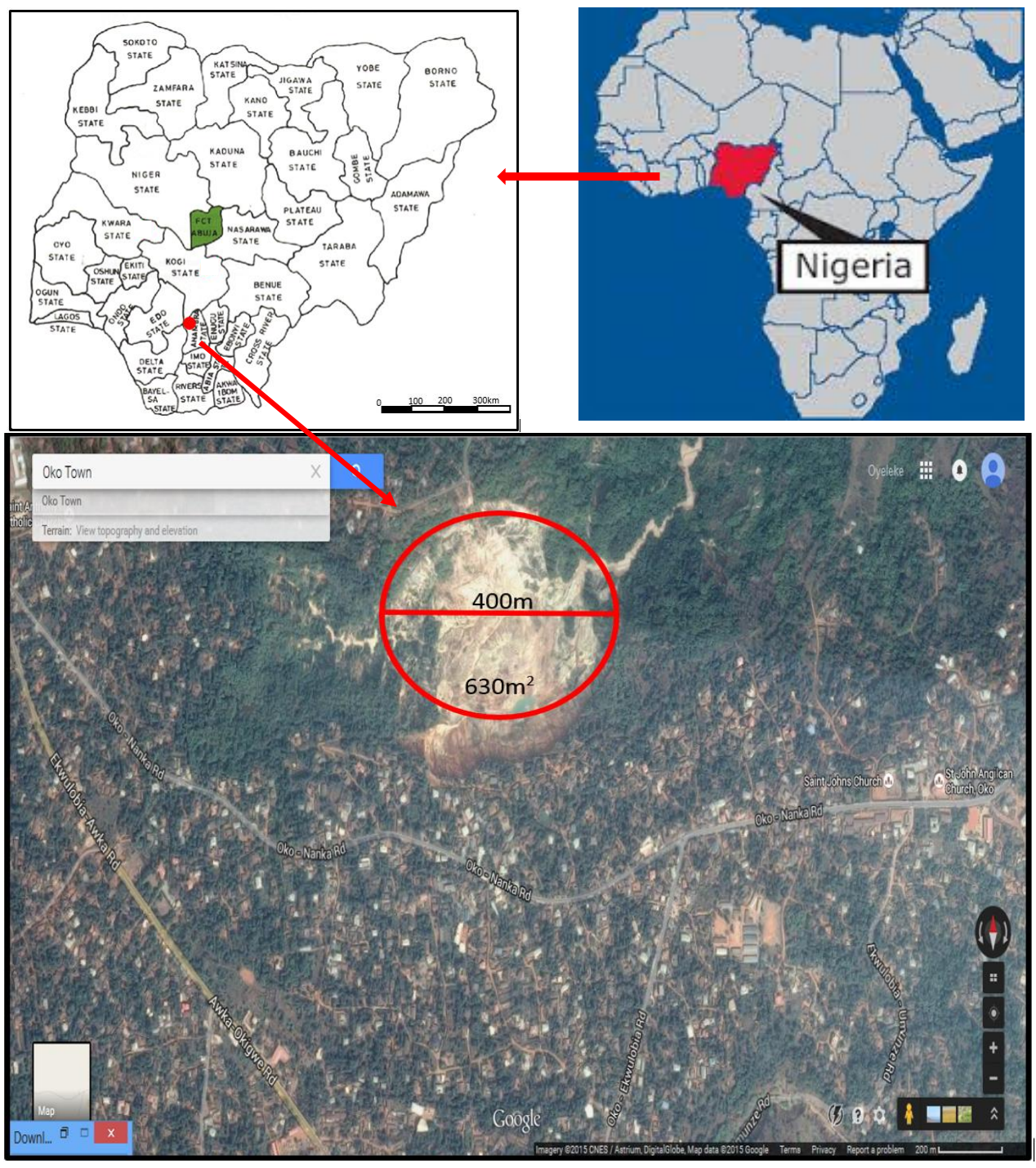

Figure 1: Satellite image of Oko area in Anambra State showing the landslide region (Red circle: Landslide affected area). 
Nat. Hazards Earth Syst. Sci. Discuss., doi:10.5194/nhess-2016-297, 2016 Manuscript under review for journal Nat. Hazards Earth Syst. Sci.

Published: 26 October 2016

(c) Author(s) 2016. CC-BY 3.0 License.

\section{Natural Hazards and Earth System Sciences \\ Discussions}

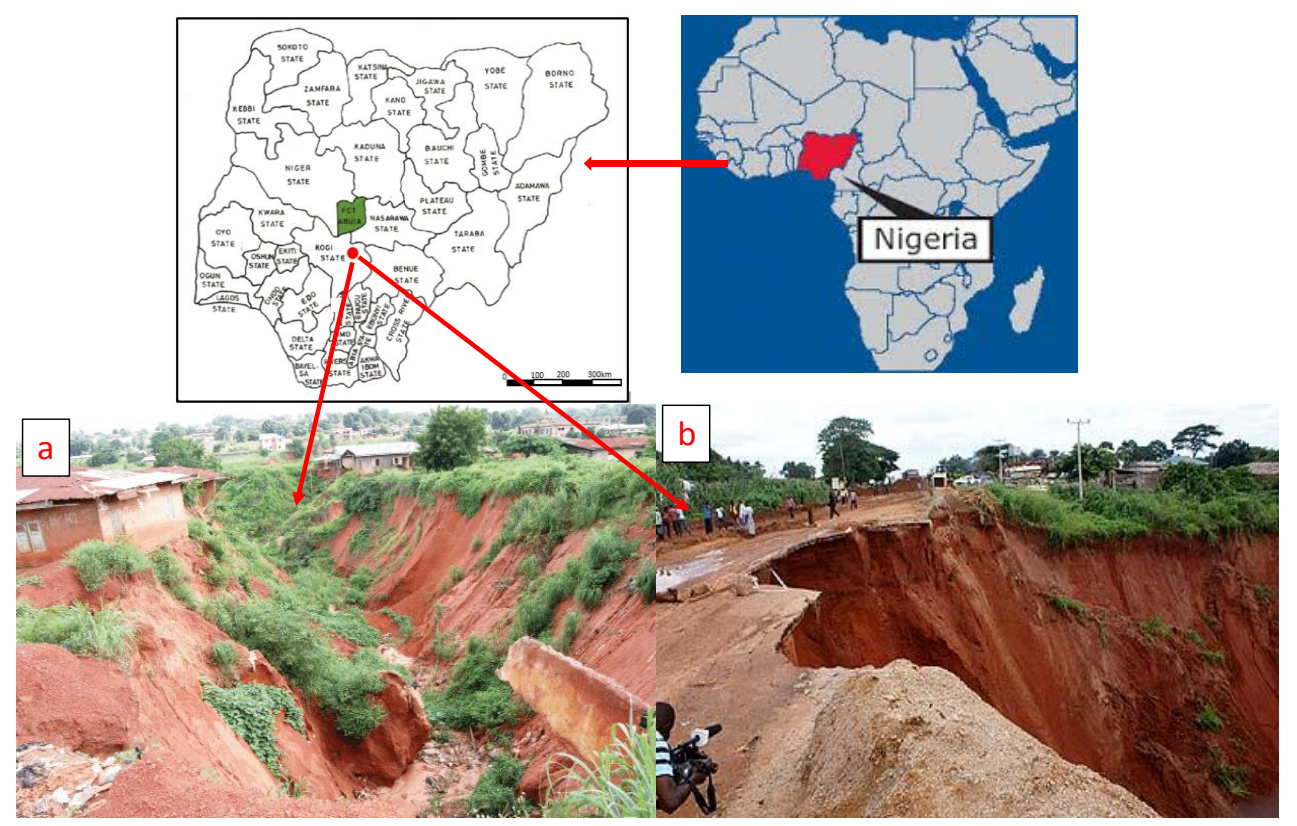

573 Figure 2: Structural failure in Lokoja (Kogi State) due to slope failure. 
Nat. Hazards Earth Syst. Sci. Discuss., doi:10.5194/nhess-2016-297, 2016

Manuscript under review for journal Nat. Hazards Earth Syst. Sci.

Published: 26 October 2016

(c) Author(s) 2016. CC-BY 3.0 License.
Natural Hazards and Earth System

Sciences

Discussions

(c) $\underset{\mathrm{BY}}{(i)}$

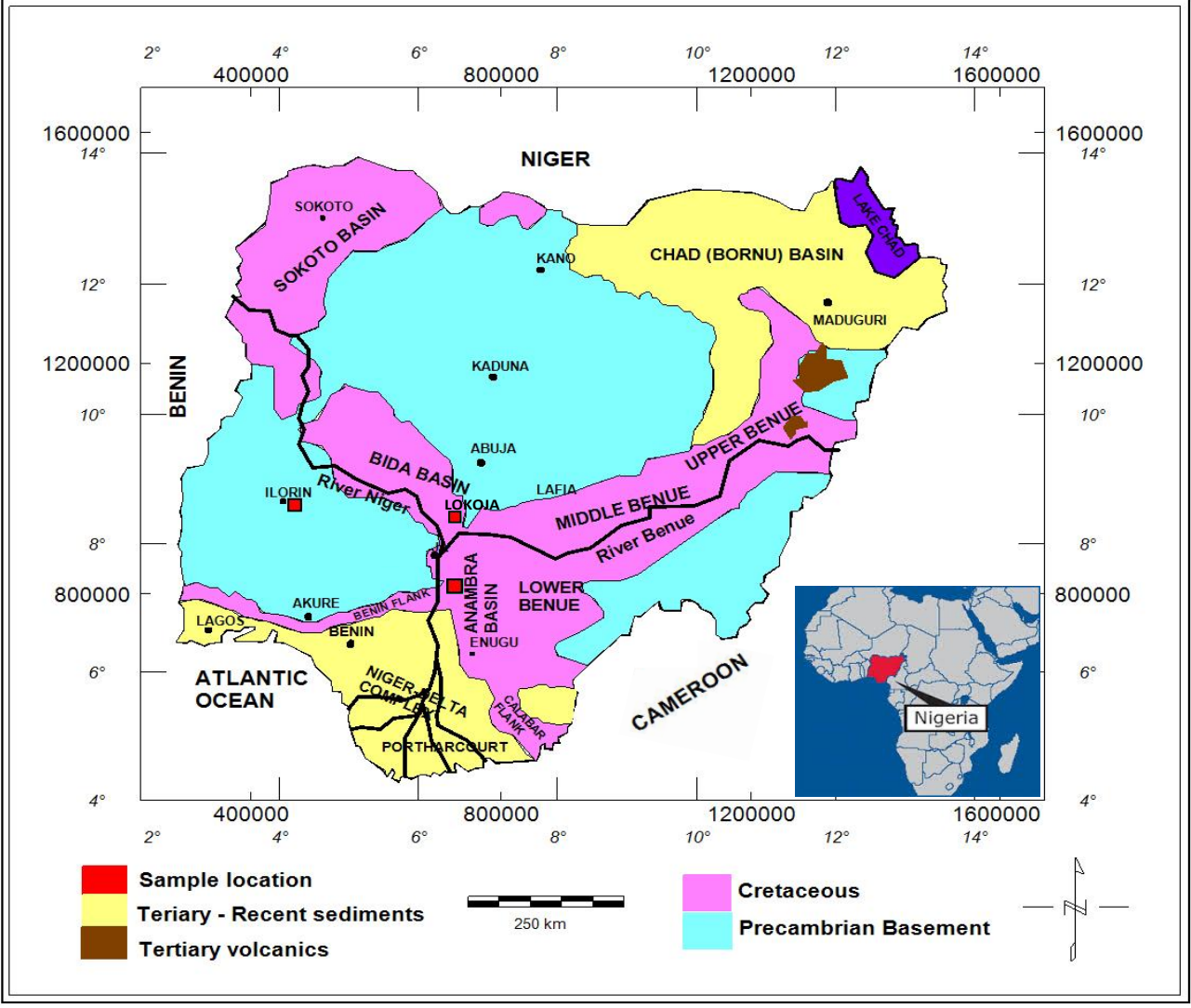

Figure 3: Geological map of Nigeria showing the major geological components and sampling location (After Obaje, 2009). 
Nat. Hazards Earth Syst. Sci. Discuss., doi:10.5194/nhess-2016-297, 2016

Manuscript under review for journal Nat. Hazards Earth Syst. Sci.

Published: 26 October 2016

(c) Author(s) 2016. CC-BY 3.0 License.

(c) (i)

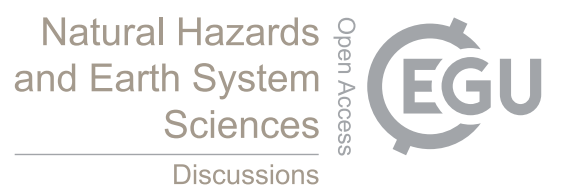

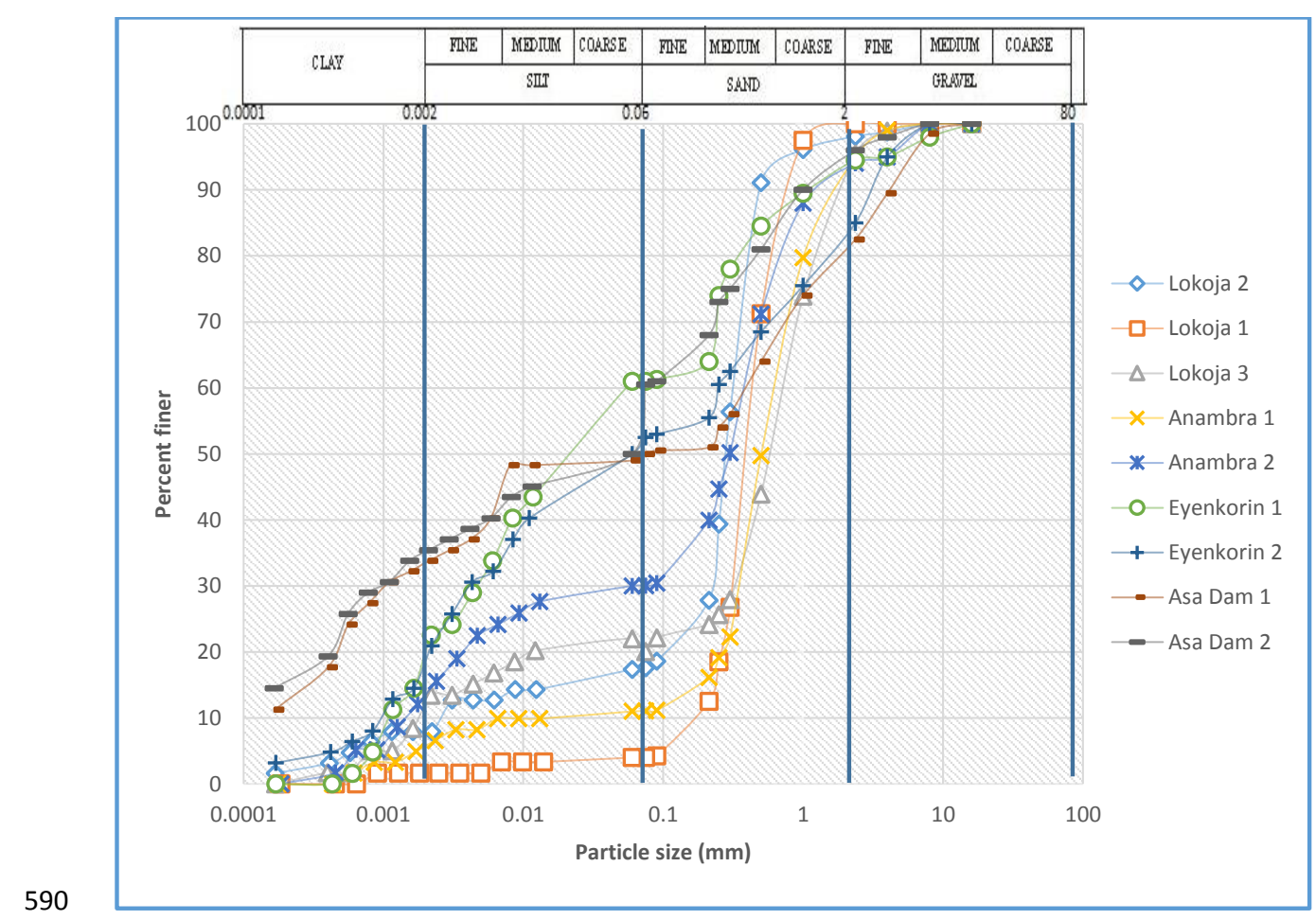

591 Figure 4: Grain size distribution curves for the soil samples.

592

593

594

595

596 
Nat. Hazards Earth Syst. Sci. Discuss., doi:10.5194/nhess-2016-297, 2016

Manuscript under review for journal Nat. Hazards Earth Syst. Sci.

Published: 26 October 2016

(c) Author(s) 2016. CC-BY 3.0 License.
Natural Hazards and Earth System

Sciences

Discussions

\begin{tabular}{|c|c|c|c|}
\hline \multicolumn{2}{|c|}{ Major division } & \multirow{3}{*}{$\begin{array}{l}\text { Group } \\
\text { symbol }\end{array}$} & \multirow{2}{*}{$\begin{array}{l}\text { Criteria } \\
F_{200}<5 ; C_{k} \geq 4 ; 1 \leq C_{z} \leq 3\end{array}$} \\
\hline \multirow[t]{16}{*}{$F_{200}<50$} & Gravels & & \\
\hline & \multirow{7}{*}{$\frac{R_{4}}{R_{200}}>0.5$} & & $F_{260}<5$; Not meeting the GW criteria of $C_{\mathrm{u}}$ and $C_{z}$ \\
\hline & & $\begin{array}{l}\text { GM } \\
\text { GC }\end{array}$ & $\begin{array}{l}F_{200}>12 ; P I<4 \text { or plots below } A \text {-line (Fig. } 4.2 \text { ) } \\
F_{2 m}>12 ; P I>7 \text { and plots on or above A-line (Fig. } 4.2 \text { ) }\end{array}$ \\
\hline & & GM-GC & $F_{200}>12 ; P I$ plots in the hatched area (Fig. 4.2) \\
\hline & & GW-GM & $\begin{array}{l}5 \leq F_{200} \leq 12 ; \text { satisfies } C_{\mathrm{u}} \text { and } C_{z} \text { criteria of } \mathrm{GW} \text { and meets the } P I \\
\text { criteria for } \mathrm{GM}\end{array}$ \\
\hline & & GW-GC & $\begin{array}{l}S \leq F_{200} \leq 12 ; \text { satisfies } C_{w} \text { and } C_{z} \text { criteria of } \mathrm{GW} \text { and meets the } P I \\
\text { criteria for GC }\end{array}$ \\
\hline & & GP-GM & $\begin{array}{l}5 \leq F_{200} \leq 12 \text {; does not satisfy } C_{u} \text { and } C_{z} \text { criteria of } G W \text { and meets } \\
\text { the } P I \text { criteria for } G M\end{array}$ \\
\hline & & GP-GC & $\begin{array}{l}5 \leq F_{200} \leq 12 \text {; does not satisfy } C_{\mu} \text { and } C_{z} \text { criteria of } \mathrm{GW} \text { and meets } \\
\text { the } P I \text { criteria for GC }\end{array}$ \\
\hline & \multirow{8}{*}{$\begin{array}{l}\text { Sands } \\
\frac{R_{4}}{R_{200}} \leq 0.5\end{array}$} & SW & $F_{200}<5 ; C_{u} \geq 6 ; 1 \leq C_{z} \leq 3$ \\
\hline & & SP & $F_{200}<5$; Not meeting the SW criteria of $C_{\alpha}$ and $C_{z}$ \\
\hline & & SM & $F_{200}>12 ; P I<4$ or plots below $A$-line (Fig. 4.2 ) \\
\hline & & & $F_{200}>12 ; P I>7$ and plots on or above $A$-line (Fig. 4.2) \\
\hline & & $\begin{array}{l}\text { SM-SC } \\
\text { SW-SM }\end{array}$ & $\begin{array}{l}\left.F_{300}>12 ; P I \text { plots in the hatched area (Fig. } 4.2\right) \\
S \leq F_{200} \leq 12 ; \text { satisfies } C_{w} \text { and } C_{z} \text { criteria of } S W \text { and meets the } P I \\
\text { criteria for SM }\end{array}$ \\
\hline & & SW-SC & $\begin{array}{l}S \leq F_{200} \leq 12 \text {; satisfies } C_{w} \text { and } C_{z} \text { criteria of } S W \text { and meets the } P I \\
\text { criteria for } S C\end{array}$ \\
\hline & & SP-SM & $\begin{array}{l}5 \leq F_{200} \leq 12 ; \text { does not satisfy } C_{\psi} \text { and } C_{z} \text { criteria of } \mathrm{SW} \text { and meets } \\
\text { the } P / \text { criteria for } \mathrm{SM}\end{array}$ \\
\hline & & SP-SC & $\begin{array}{l}5 \leq F_{200} \leq 12 ; \text { does not satisfy } C_{\psi} \text { and } C_{z} \text { criteria of } \mathrm{SW} \text { and meets } \\
\text { the } P I \text { criteria for SC }\end{array}$ \\
\hline \multirow[t]{8}{*}{$F_{200} \geq 50$} & Silts and & ML & $P I<4$ or plots below $A$-line (Fig. 4.2 ) \\
\hline & Clays & & $P I>7$ and plots on or above $A$-line (Fig. 4.2) \\
\hline & $L L<50$ & CL-ML & $\begin{array}{l}\text { PI plots in the hatched area (Fig. 4.2) } \\
\text { LL }\end{array}$ \\
\hline & & OL & $\overline{L L_{\text {(not dried) }}}<0.75 ; P I$ plots in the OL area in Fig. 4.2 \\
\hline & \multirow{3}{*}{$\begin{array}{l}\text { Silts and } \\
\text { Clays } \\
L L \geq 50\end{array}$} & $\begin{array}{l}\mathrm{MH} \\
\mathrm{CH}\end{array}$ & $\begin{array}{l}\text { PI plots below A-line (Fig. } 4.2 \text { ) } \\
\text { PI plots on or above A-line (Fio } 4.2 \text { ) }\end{array}$ \\
\hline & & & $\begin{array}{l}\text { PI plots on or above A-line (Fig. 4.2) } \\
L L_{\text {(oven eried) }}\end{array}$ \\
\hline & & $\mathrm{OH}$ & $\overline{L L_{\text {(pot dried) }}}<0.75: P I$ plots in the $\mathrm{OH}$ area in Fig. 4.2 \\
\hline & $\begin{array}{l}\text { Highly } \\
\text { organic } \\
\text { matter }\end{array}$ & $\mathrm{Pt}$ & Peat \\
\hline
\end{tabular}

Note: $C_{\mathrm{H}}=$ uniformity coefficient $=\frac{D_{60}}{D_{10}} ; C_{z}=$ coefficient of gradation $=\frac{D_{30}^{2}}{D_{60} \times D_{10}}$

$L L=$ liquid limit on minus 40 sieve fraction

$P l=$ plasticity index on minus 40 sieve fraction

598 Figure 5: Unified Classification System (Based on materials passing 75mm sieve) (Based on 
Nat. Hazards Earth Syst. Sci. Discuss., doi:10.5194/nhess-2016-297, 2016

Manuscript under review for journal Nat. Hazards Earth Syst. Sci.

Published: 26 October 2016

(c) Author(s) 2016. CC-BY 3.0 License.

(c) (i)

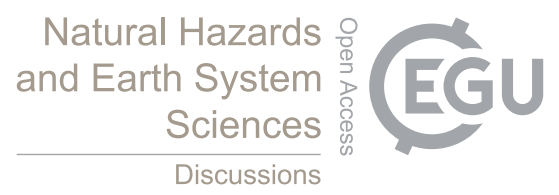

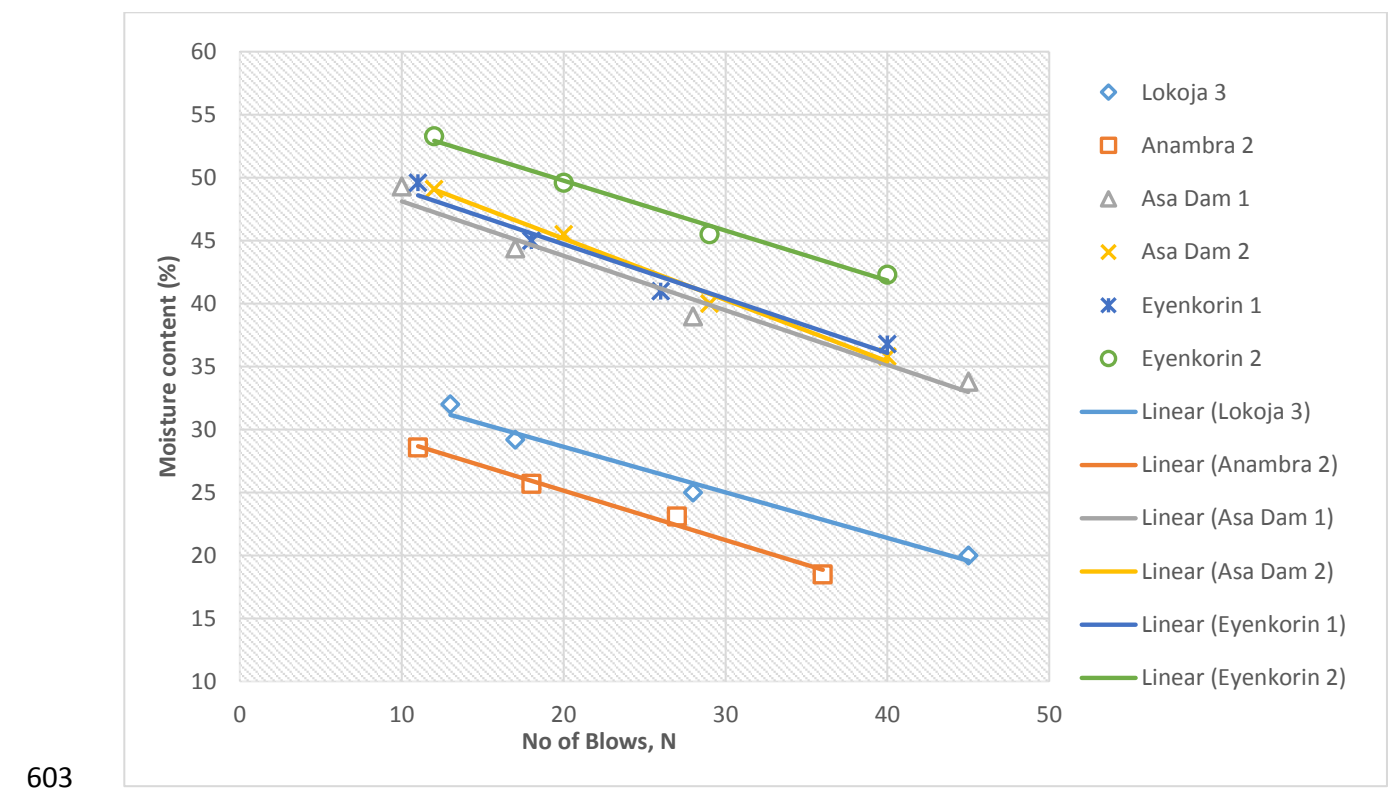

604 Figure 6: Plot of Moisture Content against No of blows, $\mathrm{N}$ for the soil samples.

605

606

607

608

609 
Nat. Hazards Earth Syst. Sci. Discuss., doi:10.5194/nhess-2016-297, 2016

Manuscript under review for journal Nat. Hazards Earth Syst. Sci.

Published: 26 October 2016

(c) Author(s) 2016. CC-BY 3.0 License.

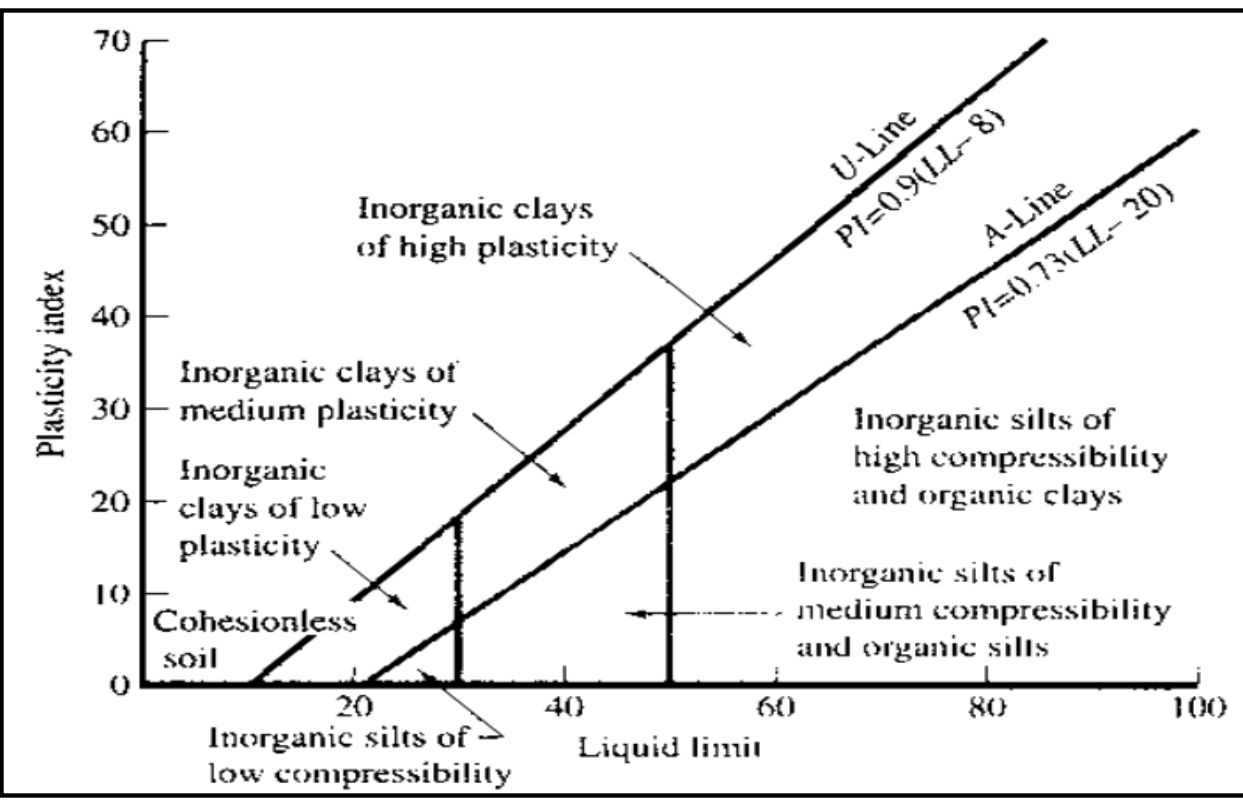

Figure 7: Standard plot of plasticity index against liquid limit (AASHTO SOIL classification system).

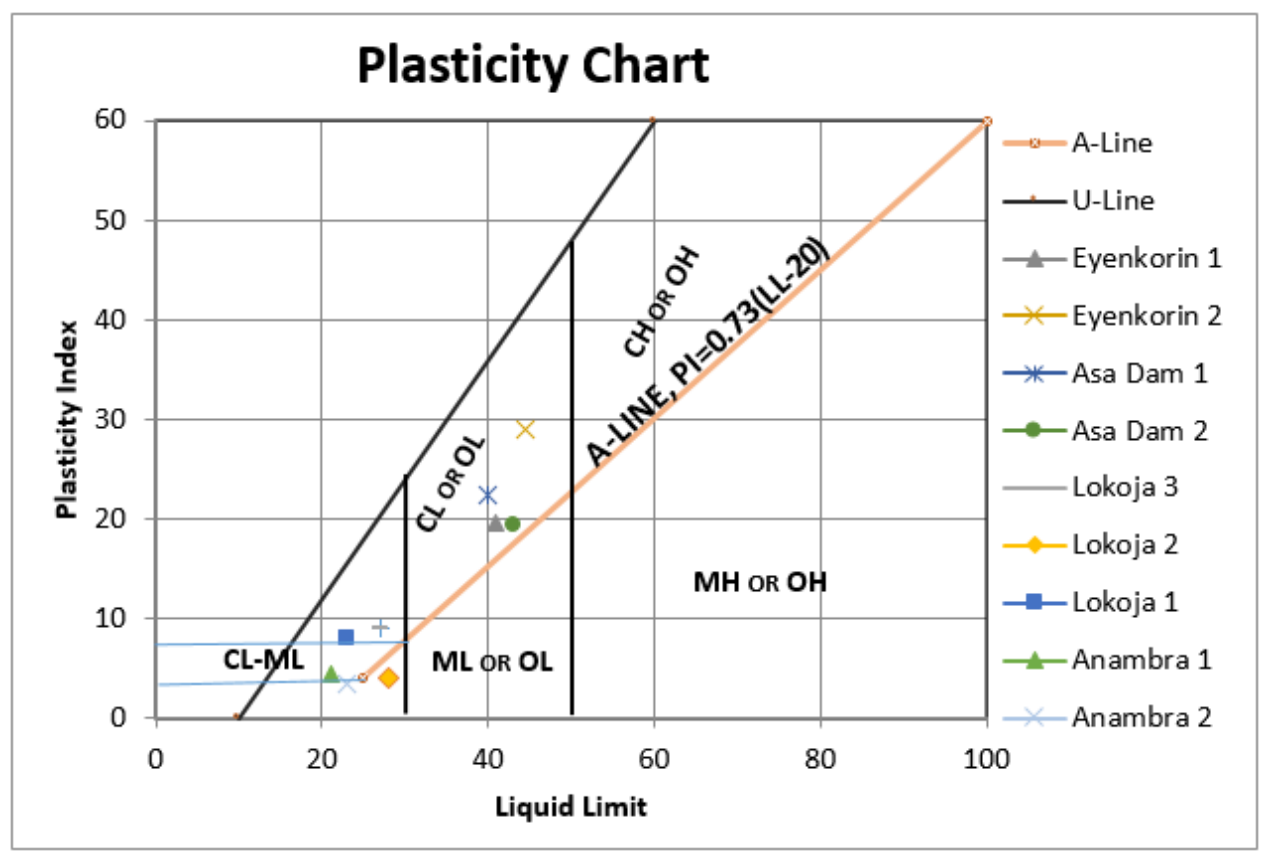

Figure 8: Plasticity chart plot for fine grained soil and fine fraction in coarse grained soil. 
Nat. Hazards Earth Syst. Sci. Discuss., doi:10.5194/nhess-2016-297, 2016

Manuscript under review for journal Nat. Hazards Earth Syst. Sci.

Published: 26 October 2016

(c) Author(s) 2016. CC-BY 3.0 License.

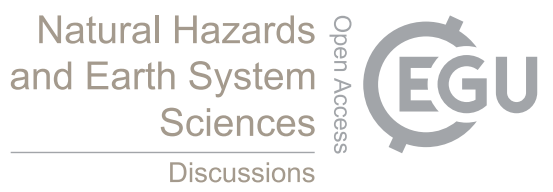

617

618

619

620

621

622

623

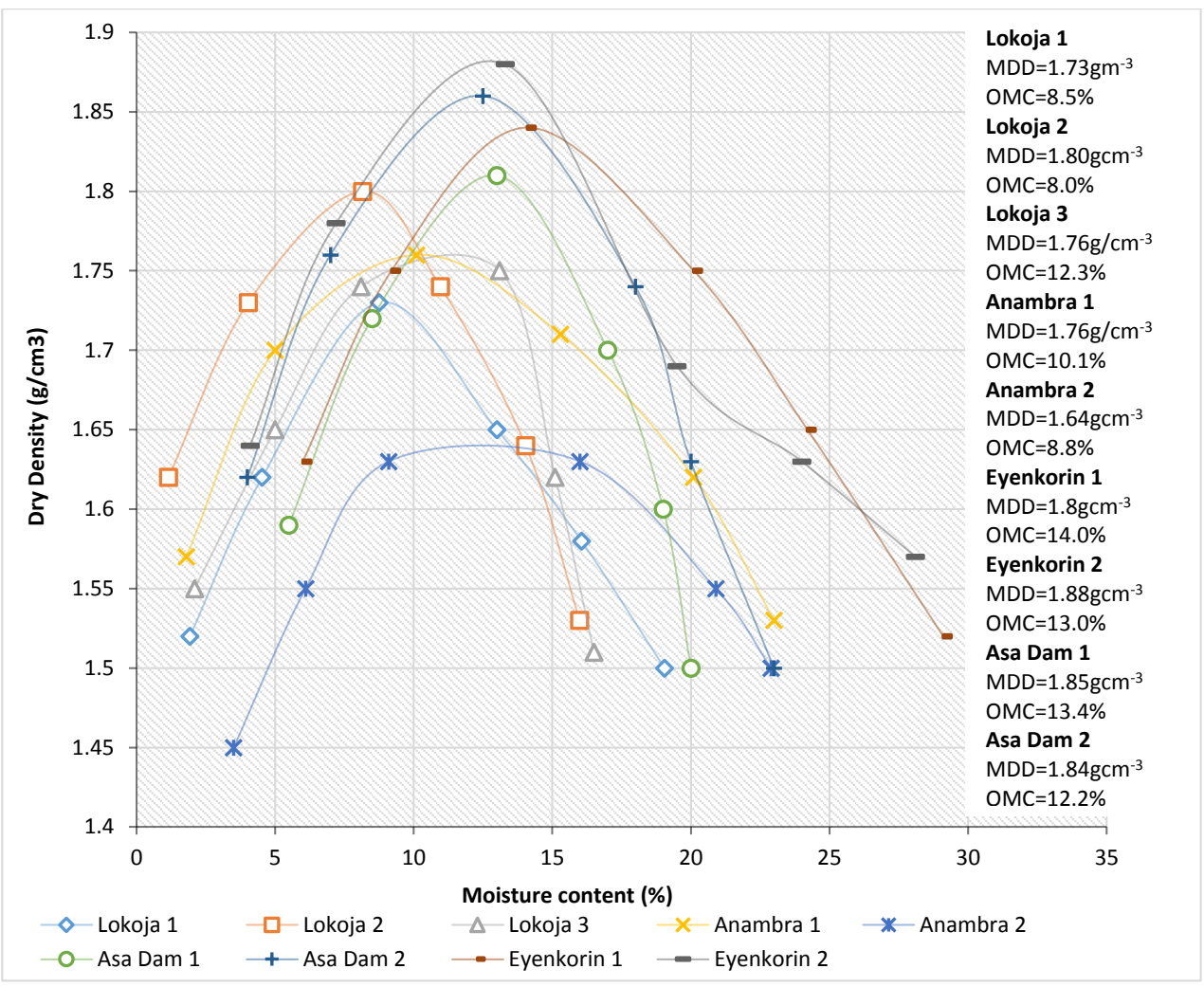

Figure 9: Compaction curves showing MDD and OMC of the soil samples. 
Nat. Hazards Earth Syst. Sci. Discuss., doi:10.5194/nhess-2016-297, 2016

Manuscript under review for journal Nat. Hazards Earth Syst. Sci.

Published: 26 October 2016

(c) Author(s) 2016. CC-BY 3.0 License.

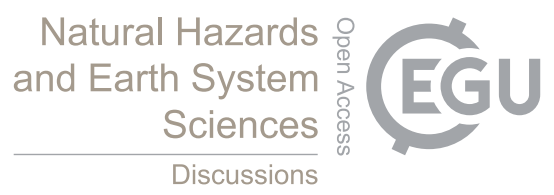

(c) (1)

624

625

626

627

628

629
Seed et al. (2003)

35

Zone A - Potentially liquefiable if $\mathrm{Wc}>0.8 \mathrm{LL}$

Zone B - test if Wc $>0.85 \mathrm{LL}$

30 Applicable for $\mathrm{FC} \geq 20 \%$ if $\mathrm{PI}>12$

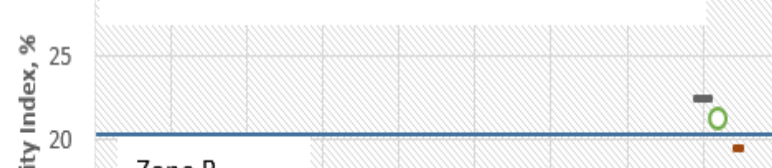

吾

要 15

10

Zone B

8

Zone A

5

0

(1)

N
0

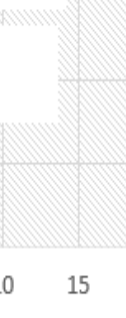

Liquid Limit, \%
口Lokoja 1

๑Lokoja 2

$\triangle$ Lokoja 3

$\times$ Anambra 2

* Anambra 1

OEyenkorin 1

+ Eyenkorin 2

- Asa Dam 1

- Asa Dam 2

x 0
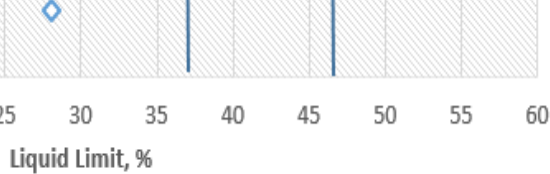

Figure 10: Plasticity chart showing the recommendations by Seed et al. (2003) regarding the assessment of "liquefiable" soil types and the Atterberg Limits of fine-grained soils. 
Nat. Hazards Earth Syst. Sci. Discuss., doi:10.5194/nhess-2016-297, 2016

Manuscript under review for journal Nat. Hazards Earth Syst. Sci.

Published: 26 October 2016

(c) Author(s) 2016. CC-BY 3.0 License.

(c) (i)

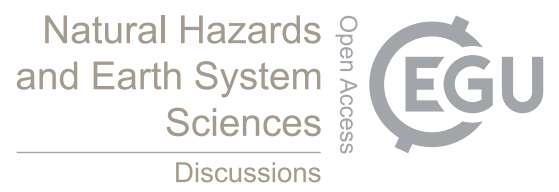

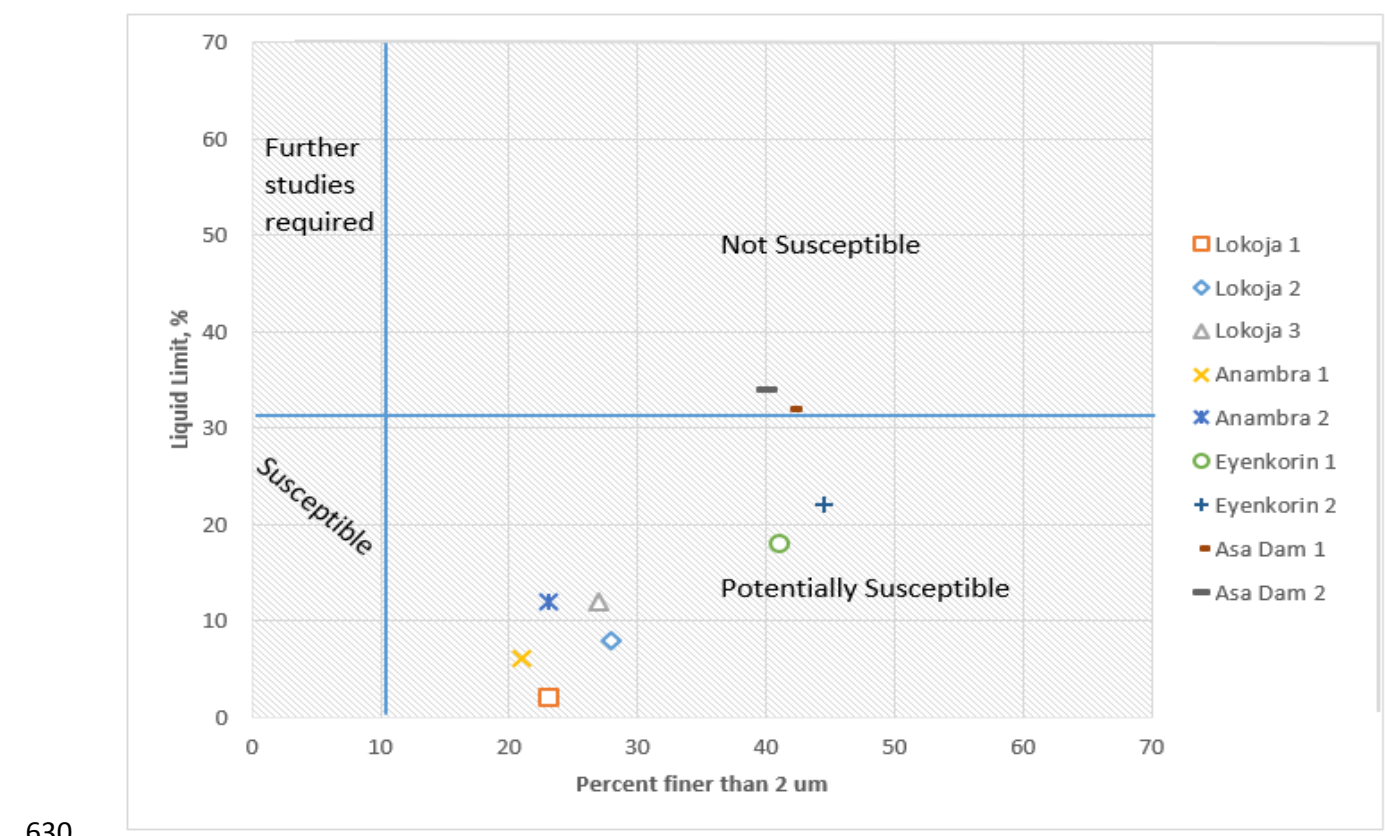

631 Figure 11: Liquefaction screening criteria after Andrews and Martin (2000).

632

633 
Nat. Hazards Earth Syst. Sci. Discuss., doi:10.5194/nhess-2016-297, 2016

Manuscript under review for journal Nat. Hazards Earth Syst. Sci.

Published: 26 October 2016

(c) Author(s) 2016. CC-BY 3.0 License.

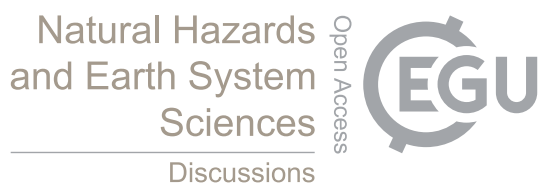

(c) (1)

634

635

636

637

638

639

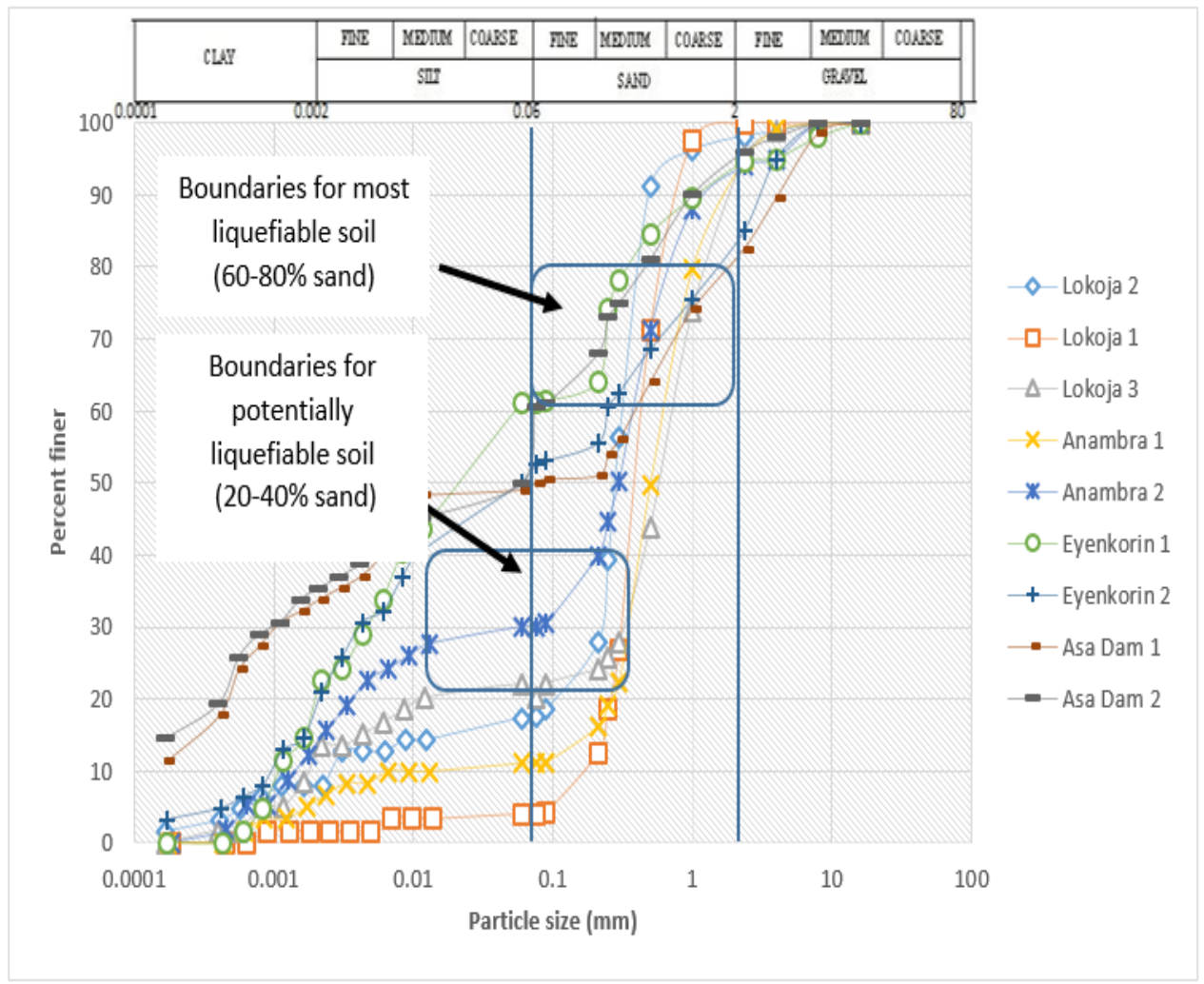

Figure 12: Boundaries in the gradation curves for soils susceptible to liquefaction (After Tsuchida, 1970). 
Nat. Hazards Earth Syst. Sci. Discuss., doi:10.5194/nhess-2016-297, 2016

Manuscript under review for journal Nat. Hazards Earth Syst. Sci.

Published: 26 October 2016

(c) Author(s) 2016. CC-BY 3.0 License.
Natural Hazards and Earth System

Sciences

Discussions

(c) $($ i)
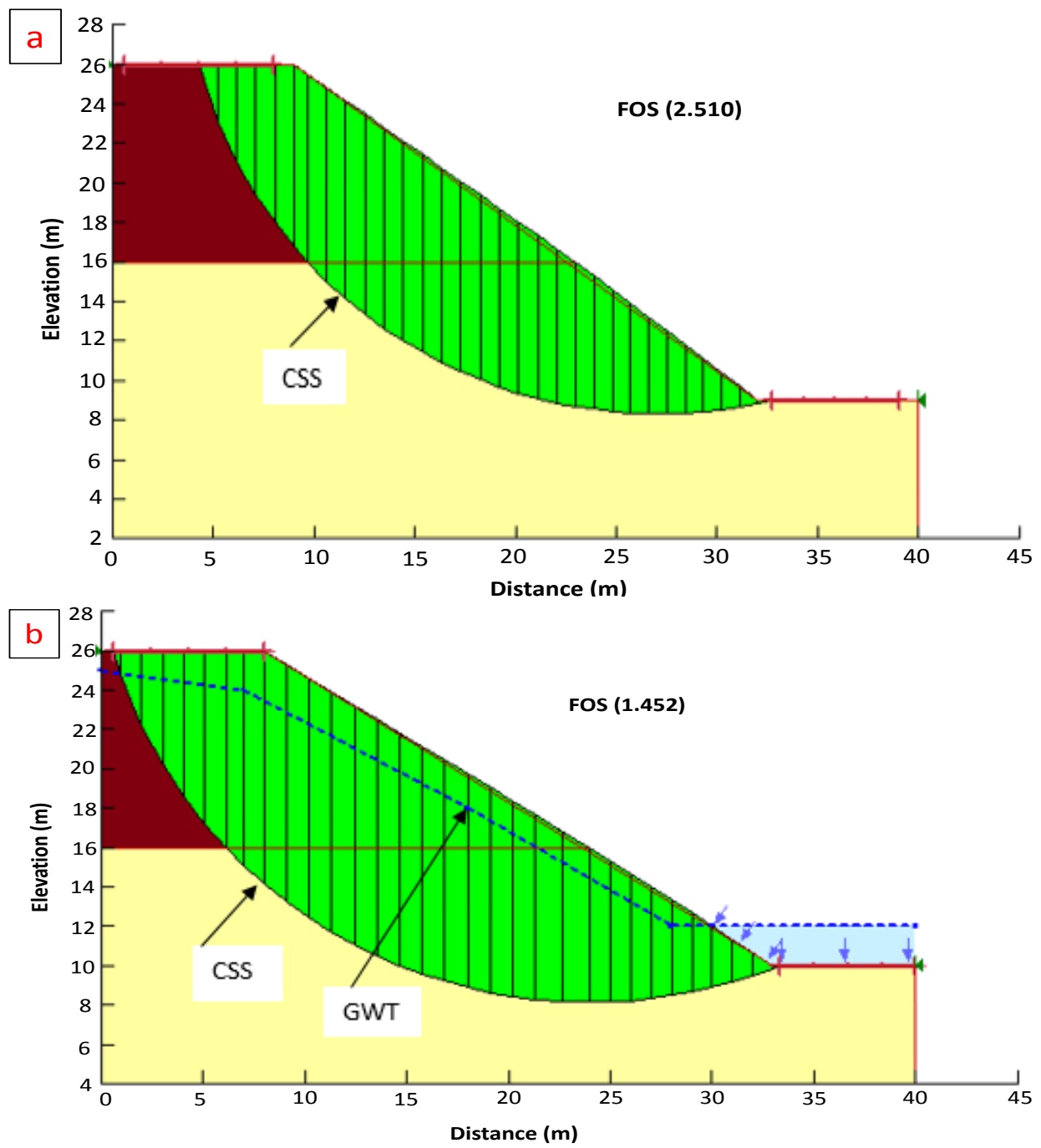

640

641 Figure 13: Non-optimised (a) dry and (b) wet slopes for Oko 1 and 2 (Anambra state).

642

643 
Nat. Hazards Earth Syst. Sci. Discuss., doi:10.5194/nhess-2016-297, 2016

Manuscript under review for journal Nat. Hazards Earth Syst. Sci.

Published: 26 October 2016

(c) Author(s) 2016. CC-BY 3.0 License.
Natural Hazards and Earth System

Sciences

Discussions

(c) $\underset{\mathrm{BY}}{(-)}$

647

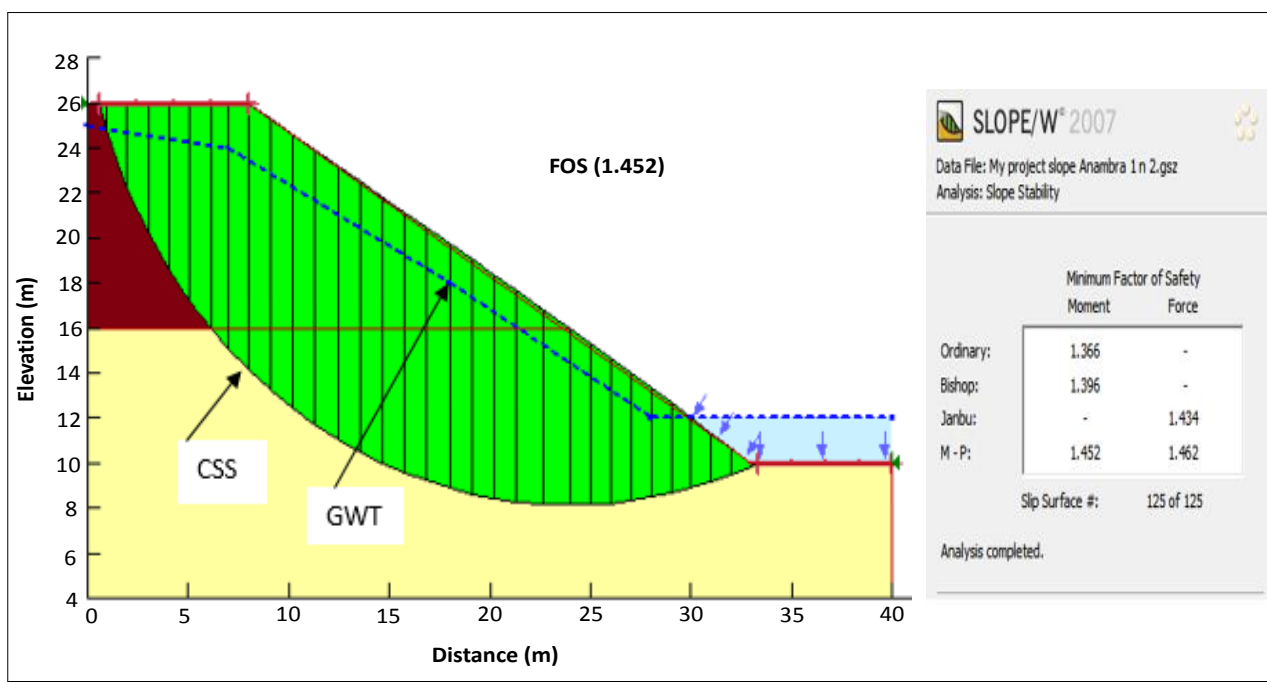

Figure 14: Non-optimised wet slope and factor of safety for Oko 1 and 2 (Anambra state).

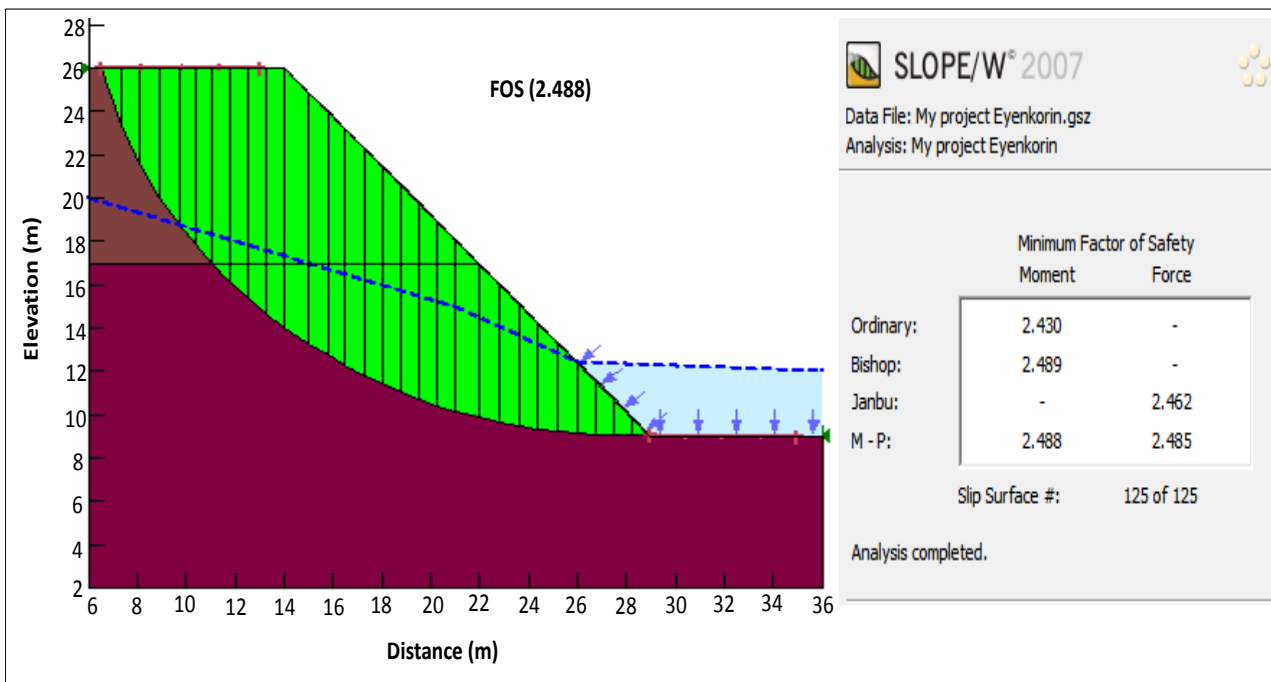

Figure 15: Non-optimised wet slope model and factor of safety for Eyenkorin 1 and 2 (Kwara). 
Nat. Hazards Earth Syst. Sci. Discuss., doi:10.5194/nhess-2016-297, 2016

Manuscript under review for journal Nat. Hazards Earth Syst. Sci.

Published: 26 October 2016

(c) Author(s) 2016. CC-BY 3.0 License.
Natural Hazards and Earth System Sciences

Discussions

(c) (i)

651

652

653

654

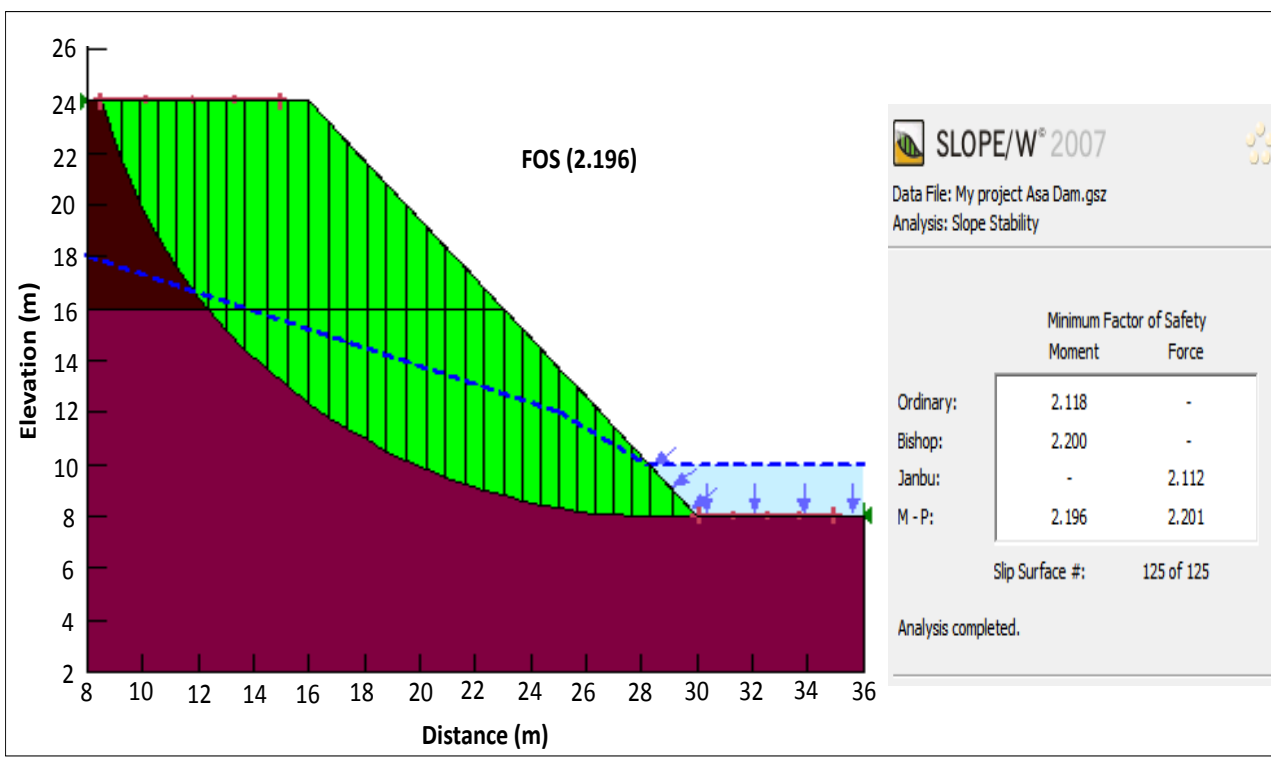

Figure 16: Non-optimised wet slope model and factor of safety for Asa Dam 1 and 2 (Kwara). 
Nat. Hazards Earth Syst. Sci. Discuss., doi:10.5194/nhess-2016-297, 2016

Manuscript under review for journal Nat. Hazards Earth Syst. Sci.

Published: 26 October 2016

(c) Author(s) 2016. CC-BY 3.0 License.
Natural Hazards and Earth System

Sciences

Discussions (c) $\underset{\mathrm{BY}}{(i)}$
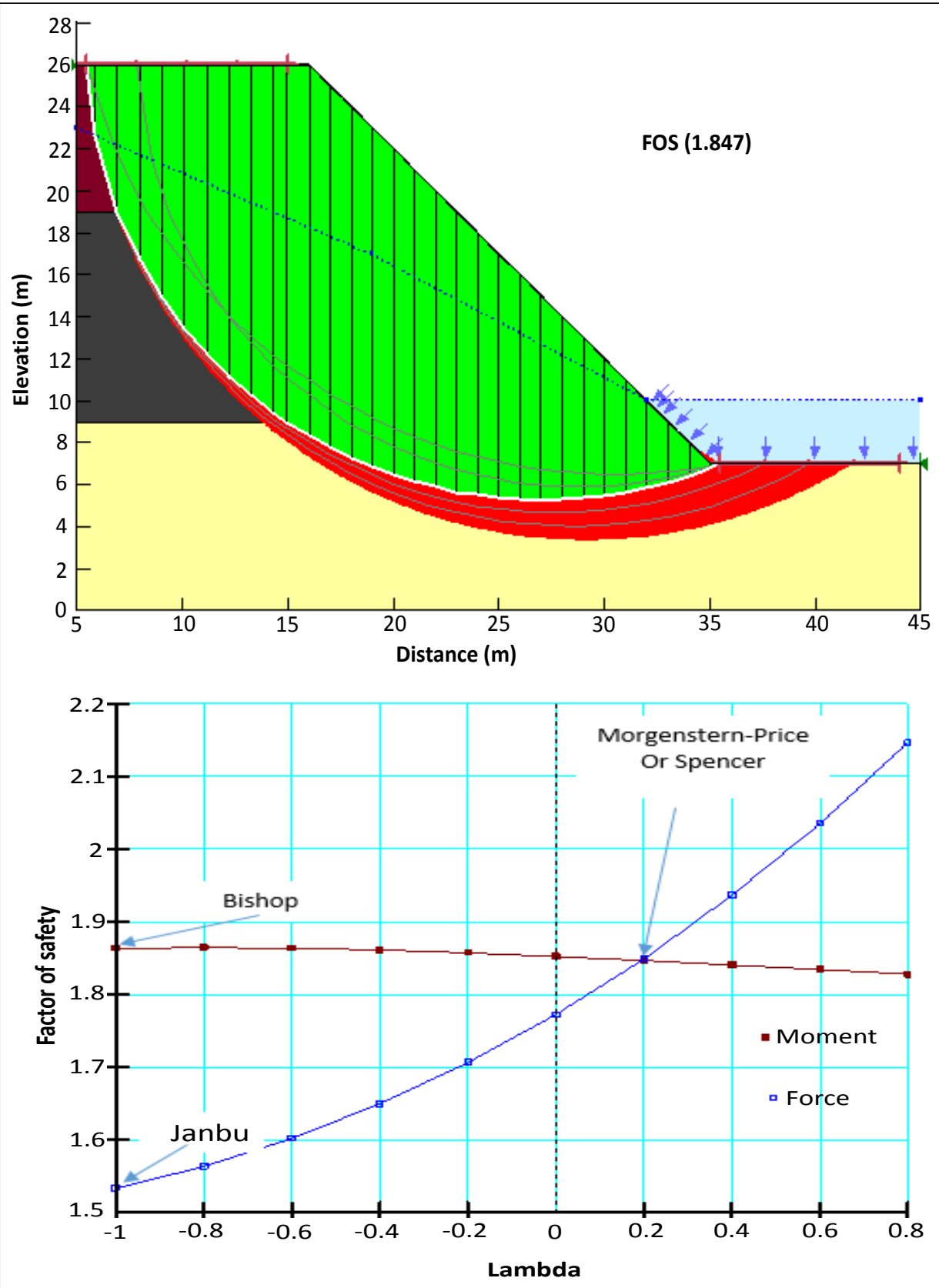

Figure 17: Critical slip surfaces and factor of safety from limit equilibrium analysis using SLOPE/W for 3 soil layers in Agbaja Hill, Lokoja (Kogi state), and plot of factor of safety versus lambda, $\lambda$ (non-optimized). 
Nat. Hazards Earth Syst. Sci. Discuss., doi:10.5194/nhess-2016-297, 2016

Manuscript under review for journal Nat. Hazards Earth Syst. Sci.

Published: 26 October 2016

(c) Author(s) 2016. CC-BY 3.0 License.
Natural Hazards and Earth System Sciences

Discussions (c) (i)
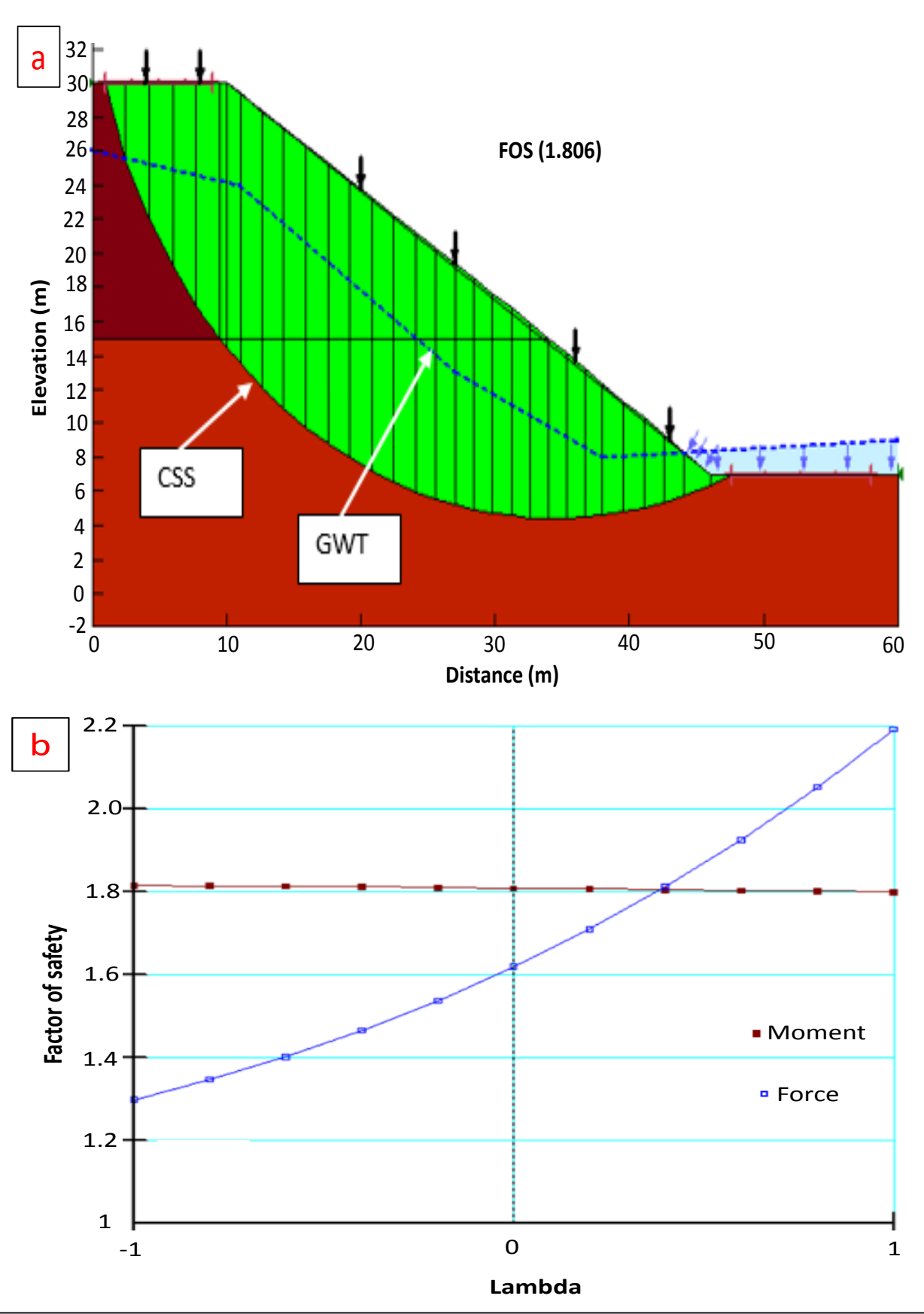

Figure 18: Showing (a) Optimised slope with point load of 40kPa, (b) Plot of FOS versus lambda, $\lambda$ (optimised) with external loads of $40 \mathrm{kPa}$. 
Nat. Hazards Earth Syst. Sci. Discuss., doi:10.5194/nhess-2016-297, 2016

Manuscript under review for journal Nat. Hazards Earth Syst. Sci.

Published: 26 October 2016

(c) Author(s) 2016. CC-BY 3.0 License.
Natural Hazards and Earth System

Sciences

Discussions

(c) (i)

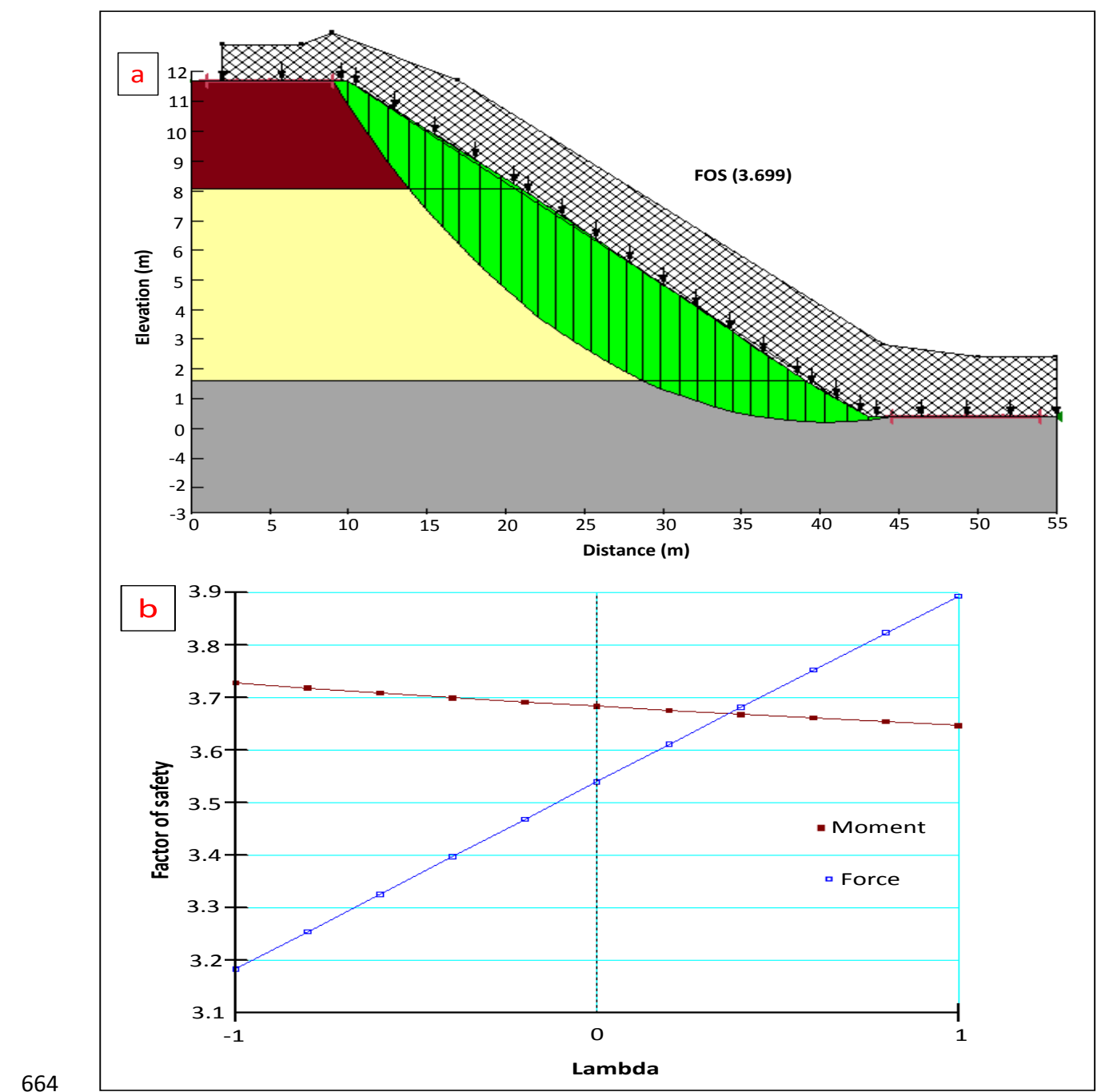

665 Figure 19: Showing (a) Optimised slope with reinforcement load of $50 \mathrm{kPa}$, (b) Plot of FOS

666 versus lambda, $\lambda$ (optimised) with reinforcement load of $50 \mathrm{kPa}$.

667 